University of Chicago Legal Forum

1987Consent Decrees: Practical Problems and Legal Dilemmas

\title{
*241 FEDERAL POLICY MAKING BY CONSENT DECREE: AN ANALYSIS OF AGENCY AND JUDICIAL DISCRETION
}

\section{Peter M. Shane}

Copyright 1987 by the University of Chicago; Peter M. Shane

A core lesson of modern administrative law is that our government of laws is profoundly a government of discretion. Many significant federal administrative decisions are not subject to any great procedural constraint as to their timing, origination, or format. To the extent administrative decisions are limited by congressionally imposed substantive criteria, those criteria frequently leave broad leeway for ultimate implementation. This state of affairs does not mean that government administrators are typically free to act merely on naked personal preference in the performance of their tasks. It does mean, however, that the forces that constrain discretion are often informal and largely beyond the capacity or desire of courts to review.

One critical executive function where discretion infuses the execution of the laws is the conduct of government litigation. Not only government decisions to bring suit, but also the host of government decisions entailed in responding to a suit, typically are left to the near-plenary discretion of the Attorney General and subordinate lawyers. These decisions include whether and on what terms to settle litigation--choices that obviously have a great potential impact on the implementation of public policy through litigation.

Courts and administrative lawyers have recently expressed substantial concern with one set of settlement decisions that doubly involve the exercise of discretion. These are discretionary *242 decisions to settle lawsuits through commitments that curtail the future exercise of government discretion with respect to particular subjects or particular parties. Such commitments may be embodied in consent decrees or other settlement agreements. Judge Wilkey of the District of Columbia Circuit, reviewing one such discretion-binding consent decree, has gone so far as to warn of the "evil(s) of government by consent decree," including what he believes to be "its potential to freeze the regulatory processes of representative democracy." Last year, the Attorney General promulgated guidelines intended to prevent future resort to such decrees.

Part I of this article describes discretion-limiting consent decrees. The remainder of the article addresses the legal and policy problems that they pose. The first set of legal issues concerns the substantive limits on the permissibility of the decrees. Such limits pertain to both executive authority to enter agreements that bind future exercises of executive discretion, and judicial authority to approve such agreements. A second set of legal issues concerns the impact of such decrees on third parties, and the adequacy of existing procedures to protect third-party rights. The policy issues center on the appropriateness of executive acquiescence in a model of public law that, as explained below, legitimates a potentially significant degree of judicial supervision of administrative policy making. An informed assessment of the legality and appropriateness of discretion-limiting consent decrees must account for each of these sets of issues. 


\section{*243 I. DISCRETION-LIMITING DECREES: AN INTRODUCTION TO THE PROBLEM}

Because consent decrees are judgments, and all judgments--even in government litigation-are binding on the parties to the immediate suit, it may not be immediately obvious why the discretion-limiting features of some consent decrees have recently attracted so much criticism. It is thus helpful to reflect on both the nature of executive policy-making discretion in general, and on the facts of several cases that illustrate the legal and policy concerns that arise in connection with discretion-limiting decrees.

A. Revisable and Nonrevisable Discretion

The Constitution and a host of statutes vest in the executive a wide range of decisionmaking powers that are deeply imbued with discretion. That is, the timing, content and even the initiation of many policies are left to the educated judgment of the designated decision maker with the prospect, at most, of deferential judicial review for rationality. That does not mean, however, that the legal implications of all discretionary decisions are the same. They are not. Some decisions, though not at all mandatory, may significantly limit the decision maker's legal discretion to make future decisions on the same subject matter, while other discretionary decisions do not have this effect.

*244 Presidential pardons are perfect examples of discretionary decisions that limit the decision maker's future discretion. No one is entitled to a presidential pardon; whether to pardon a person and why are left entirely to the President's discretion. Yet, once a President executes a pardon, there is no prosecuting the pardoned person for the relevant offense. Even though the President and his successors have a constitutional obligation to take care that the laws be faithfully executed, and even though the President or his successors may come to regret the pardon as unjustified, there is no further prospect of prosecution. Legally, the initial exercise of discretion is nonrevisable.

In contrast, many acts of discretion by executive officials have only a limited, if any, legal impact on the future discretion of the decision maker. For example, if the President exercises discretion today to urge Congress to fund his Strategic Defense Initiative, he is free tomorrow to repudiate his views and urge unilateral disarmament. He may appear inconsistent, but his inconsistency is plainly lawful. Likewise, the President may nominate today a particular individual for a federal judgeship and, tomorrow, refuse to appoint that person to his or her post. He may do so even if the Senate has consented to the appointment. Until he signs the judge-designate's commission, the President's act of discretion is revisable by him.

The easiest way of characterizing the concern that apparently animates the criticisms of Judge Wilkey and others is that some government consent decrees have the effect of rendering decisions that, outside the context of litigation, would ordinarily be exercises of substantially revisable discretion, into discretionary decisions that are substantially less revisable or, indeed, wholly nonrevisable.

Not all settlement agreements or consent decrees have this impact. For example, the United States might, in a tort suit, agree to settle a plaintiff's claim for a particular sum. It need not agree to settle; the decision is discretionary. Once the settlement is made, however, it is enforceable 
against the United States. Therefore, the promise to settle is a relatively nonrevisable discretionary promise.

*245 Promises by the United States to pay money in return for consideration, however, are typically nonrevisable promises, whether made in consent decrees or otherwise. Any government contract is binding within the framework Congress has provided for the enforcement of contracts, even if the contracting decision is itself initially discretionary. Therefore, the fact that a promise to pay damages arises in the specific contractual context of settling a lawsuit does not affect the ordinary status of the contracting decision as one that is nonrevisable. The legal impact of a contracting decision on future government decisions with respect to the other contracting party is the same, whether or not the decision is made in the shadow of litigation.

Consider, in contrast, an agency promise to investigate a particular subject matter area as the possible target for rule making or other law enforcement. An agency might be tempted to proffer such a promise in a lawsuit challenging the agency's failure to enforce a particular regulatory statute. Such a promise, if made unconditionally, would seemingly become enforceable if embodied in a consent judgment. It would be a relatively nonrevisable promise, much like the promise to pay damages.

Outside the context of litigation, however, such a promise would be completely revisable. The Administrator of the Environmental Protection Agency ("EPA") might today address a convention of environmental protection groups and promise to investigate a particular industry that is suspected of polluting the air or water in violation of a federal antipollution statute. Should the Administrator later decide to devote enforcement resources to a wholly different industry under the same statute, however, there would be no legal sanction for that change of mind. The promise would carry none of the future-binding impact that it does in the context of a consent decree.

In general, it is such settlements--settlements that turn relatively revisable discretionary decisions outside the litigation context into significantly less revisable discretionary decisions under consent judgments-- that are at the core of recent criticism. It should be emphasized, however, that a superficial comparative view of agency discretion--revisable outside the litigation context, nonrevisable under a consent decree--may not fully appreciate a defendant agency's position in litigation. The agency's act of discretion in settling a lawsuit occurs in the shadow of litigation that $* \mathbf{2 4 6}$ ight establish agency liability for implementing a remedy. Should the agency lose the lawsuit, it might be required to submit a remedial plan for the trial court's approval or otherwise demonstrate to the court its compliance with its legal obligations. Once embodied in a judgment, such an order, like a consent decree, would permit subsequent judicial supervision of agency policy making. Thus, the constraint on discretion embodied in a consent decree may be greater than the agency would enjoy absent litigation, but not different in kind from the constraint that would exist if the agency went to trial and lost.

B. Illustrative Cases

A brief summary of several recent cases helps make concrete the problem just identified with respect to discretion-limiting consent decrees. 
1. Managerial Discretion: Citizens for a Better Environment v. Gorsuch. Between 1973 and 1975, five environmental groups sued the EPA for failure to enforce properly the Federal Water Pollution Control Act ('cFWPCA”), now called the Clean Water Act. Two cases charged EPA with failing to meet certain statutory deadlines for promulgating final effluent standards for toxic substances EPA had already listed as requiring statutory control. A third case charged EPA with using improper criteria for deciding which toxic pollutants were to be subjected to control and thus failing to include certain named toxic substances within its regulatory program. The final case charged EPA with failing to promul- gate $* 247$ certain pretreatment standards for toxics.

EPA subsequently entered settlement negotiations with the plaintiffs and with four industry intervenors in the toxic criteria case. Over the objections of three intervenors, EPA and the plaintiffs agreed to a settlement amounting to "a detailed, comprehensive regulatory program for implementation by EPA of the toxic pollutant control and pretreatment objectives” of the FWPCA. The EPA decree did not dictate the substantive terms of any regulation. It did specify, however, the general strategy EPA would employ in regulating toxics. The decree also targeted particular industries and specific pollutants for investigation for possible regulation, and specified deadlines by which regulations would be issued and compliance demanded.

In 1977, the dissenting industry intervenors moved to vacate the consent decree on various grounds, including its alleged supersession by the Clean Air Act of 1977. The district court, with EPA's support, upheld the decree. On appeal, the Court of Appeals for the District of Columbia Circuit upheld the district court, but remanded on an issue not fully argued below-- whether judicial approval of the original decree was improper because the decree impermissibly curtailed EPA's regulatory discretion. On remand, EPA joined the intervenors in seeking to remove from the decree any discretion-limiting provisions.

The district court on remand rejected the intervenors' arguments, and the Court of Appeals affirmed. In essence, both courts regarded EPA's commitments with respect to the management of its regulatory program to have been statutorily authorized as a means both for implementing the underlying law and for compromising the litigation against EPA. Over the vigorous dissent of Judge Wilkey, the Court of Appeals panel rejected the argument $* \mathbf{2 4 8}$ that courts could approve only those details of a consent decree that represented legitimate remedies for particular violations of the underlying statute. Such a holding, the panel argued, would itself be an unauthorized constraint on the agency's discretion in the conduct of litigation.

In this case, it is clear that EPA's settlement converted acts of ordinarily revisable discretion into acts of significantly less revisable discretion. The clearest example is EPA's agreement to target twenty-one major industries for investigation. Some of the specified industries were targeted by the FWPCA for investigation; others were not. Ordinarily, the choice of targets for prosecutorial investigation beyond those specified by statute is entirely within the agency's discretion. By contrast, under the consent decree, EPA could change its investigative strategy only with the court's concurrence in the justifiability of a modification of the decree. The very requirement that it proffer a reason for its proposed changes diminished the revisability of the targeting decision significantly. 
2. Budgeting Discretion: United States v. Board of Education of the City of Chicago. In 1980, the Justice Department decided to initiate a desegregation suit against the Chicago Board of Education unless negotiations could produce a voluntary school desegregation plan. On September 24, 1980, a federal district court approved a consent decree providing for the voluntary desegregation of the country's third-largest school system. The decree was unusual because it imposed obligations not only on the defendant $* \mathbf{2 4 9}$ school board, but also on the United States. Specifically, the decree provided: "Each party is obligated to make every good faith effort to find and provide every available form of financial resources adequate for the implementation of the desegregation plan.”

When the Reagan Administration took office in 1981, part of its agenda was the dismantling of the U.S. Department of Education, a reduction in the growth rate of federal spending for education, and a reduction in categorial federal education aid, that is, aid specifically targeted for particular purposes such as desegregation. The Administration's legislative activities on behalf of these goals had the effect of reducing the prospect for appropriations that might result in federal funding for Chicago.

The Board of Education sought to have the United States held in contempt for failing to meet its obligations under the consent decree. It argued that the obligation to "find and provide every available form of financial resources" contemplated a duty actually to assist the desegregation effort with funds that were or might become available to the Department of Education for that purpose, and not to discourage such funding. The Justice Department responded that the consent decree did not embody any affirmative funding obligation, but only the obligation to assist Chicago in locating and applying for funds that had been earmarked by Congress for school desegregation.

The district court agreed with the Board of Education's position. Without specifically defining the decree's obligatory language, the court concluded that the Administration's efforts to reduce the amount of funding that might be available to Chicago was a bad faith departure from the decree. Conceding that it was going beyond the terms of the decree, the court ordered the executive to seek to make sufficient funding available to Chicago to finance the desegregation effort in 1983-84. This obligation included a requirement to seek further funding from Congress, as needed.

The Court of Appeals upheld the district court's determina-tion $* \mathbf{2 5 0}$ that the United States obligated itself to do more than help Chicago to locate funding programs and to file applications. Nonetheless, it vacated the lower court's order. The Court of Appeals was concerned that a finding of Administration bad faith based on its legislative recommendations might raise "a significant constitutional issue.” Moreover, the Court of Appeals determined it a sufficient ground to sustain some affirmative relief that the lower court found that the Secretary of Education currently had available to him discretionary funds that he had failed to make available to Chicago.

On remand, the district court required the United States to make a good faith effort to provide financial resources adequate for implementation of the school board's desegregation plan. The United States continued to resist any affirmative obligation of funds to Chicago, however, and submitted an alternative plan for compliance with its obligations. This plan promised priority to 
Chicago in the distribution of funding under existing federal programs. The district court determined that the United States was still in violation of the consent decree, and again ordered it to pay the full shortfall sustained by Chicago in funding its desegregation effort in 1984-85. The Court of Appeals vacated the order, concluding that granting priority funding to Chicago would comply with the consent decree. It remanded, however, for a further evidentiary determination "whether the Board is receiving the maximum level of funding that is available under the criteria of programs through which funds for desegregation can be disbursed.”

The United States' promise in the consent decree to "find and provide every available form of financial resources" for Chicago desegregation rendered less revisable what otherwise would have been completely revisable executive discretion. The impact would have been greatest, of course, had the Court of Appeals agreed that the consent decree operated as a limitation on the executive's future discretion to recommend budgetary measures to Congress. Outside the context of litigation, an executive branch promise to support funding for one cause today imposes no legal limit whatsoever on its discretion to oppose that same funding tomorrow.

*251 Even if the decree is read more narrowly--only as a promise to grant Chicago some form of funding priority within existing programs--that kind of budgetary decision, outside the litigation context, would likewise be revisable unless constrained by statute. The decision to constrain discretion in this way is all the more notable because the United States was the plaintiff and not the defendant in this suit. The United States did not limit its discretion over budgeting in order to avoid the judicial imposition of liability for funding Chicago school desegregation; instead, the United States committed itself to assisting Chicago in order to facilitate Chicago's compliance with its legal obligations to minority students and to the United States.

3. Rule-Making Discretion: Ferrell v. Pierce. In early 1986, Assistant Attorney General Charles J. Cooper cited a dispute over the administration of a federal mortgage relief program as a case that lent impetus to the Attorney General's Guidelines curbing discretion-limiting decrees. The decree at issue in that case, Ferrell v. Pierce, was actually not discretion-limiting in the sense addressed by the Attorney General's Guidelines, however. The court denied a motion by the Department of Housing and Urban Development ("HUD”) to modify the decree, not because the decree limited discretion HUD otherwise enjoyed in the design of its program, but because HUD lacked authority under the governing statute to administer its program as the modification contemplated. Nonetheless, a review of Ferrell suggests how a consent decree might have an impact on the substantive bounds of permissible agency rule making.

In 1973, various plaintiffs filed a class action against HUD charging HUD with failing, in violation of the National Housing Act and other statutes, to provide mortgage foreclosure relief to holders of various HUD-insured mortgages. They claimed that HUD's failure to provide such relief led to premature foreclosures $* \mathbf{2 5 2}$ against low-income mortgagors who, with some assistance, could have met their mortgage obligations.

HUD agreed in 1976 to a consent decree under which it promised to establish a mortgage relief program. Specifically, HUD agreed to criteria under which it would accept an assignment from a mortgage of the HUD-insured obligation upon which the mortgagor had defaulted. In addition, HUD promised (a) to adopt time limits for processing mortgagors' applications for 
mortgage assignments, (b) to require mortgagees not to foreclose pending HUD action on the mortgagors' applications, and (c) to work out repayment plans (called "forebearance agreements") with qualifying mortgagors after the assignment of their obligations to HUD.

In 1979, the plaintiffs complained to the court that HUD was routinely erring in the processing of assignment applications. HUD and the plaintiffs subsequently agreed to a revised settlement under which HUD would operate the assignment program for five years under a newly revised HUD handbook. During that five years, the handbook could be revised, but only after notice to plaintiffs' counsel and only if the "basic rights" of participating mortgagors remained protected. At the end of five years, HUD would be free to decide to continue the assignment program or to adopt an "equivalent substitute."

In 1979, an assignment program was the only form of mortgage relief that HUD possessed statutory authority to adopt. In 1980, however, Congress amended the National Housing Act to permit a Temporary Mortgage Assistance Program ("TMAP") that *253 would not involve an assignment of the mortgage to HUD. This strategy was intended to be less expensive for HUD, which would not be required to pay the mortgagee for the assignment of the entire obligation. HUD promptly drafted TMAP implementing regulations and sought modification of the 1979 revised settlement to reflect the change in the law.

Yet, the Seventh Circuit upheld the denial of HUD's motion to abandon the assignment program in favor of a TMAP. HUD's proffered alternative program was, in several respects, less advantageous for participating mortgagors than the 1979 assignment program, and thus, according to the Seventh Circuit, was in violation of the legislative intent behind Congress's 1980 enactment. Consequently, the particular TMAP that HUD proposed in 1980 would have been beyond HUD's discretion under the 1980 statute, whether adopted in the context of litigation or otherwise.

Ferrell suggests the capacity of consent decrees to render statutory discretion over rule making less revisable when such discretion would exist outside of litigation. It is unclear from the Seventh Circuit's dicta whether the court would have regarded HUD as entitled to a modification of its consent decree obligations if, outside the context of litigation, the TMAP it proposed would have been authorized under the 1980 Act. If the court had considered the proposed alternative as authorized, but still denied the requested modification, then the 1979 settlement would have rendered HUD's substantive rule-making discretion significantly less revisable than it would have been without the decree.

$* * *$

These three cases illustrate the capacity of consent decrees to render less revisable executive discretion regarding the management of law enforcement, budgeting, and administrative rule making. They illustrate the capacity of consent decrees to have this impact whether the United States is plaintiff or defendant, and whether the executive discretion involved is statutorily or constitutionally based. The remainder of this article discusses the legality and appropriateness of such decrees.

*254 II. SUBSTANTIVE LIMITS ON DISCRETION-LIMITING CONSENT DECREES 
The threshold problem raised by discretion-limiting consent decrees is, of course, the degree to which they are substantively lawful. Because consent decrees are, by their nature, part contract, part judicial act, two types of limits arise as to their substantive legality. First, because the decree embodies a contract, it depends on a lawful agreement between the parties. One question that thus arises with respect to discretion-limiting decrees is whether the executive has authority to limit its discretion through a settlement agreement. Second, because a decree is part judicial act, it is constrained also by the legal limits on judicial authority. A second question that arises about discretion-limiting decrees, therefore, is whether a court has power to approve them.

A. Executive Authority to Bind Executive Discretion

It is patent that not all executive promises to render administrative discretion less revisable would be legally permissible. Any such promise made in the settlement of litigation is itself an act of discretion, and must rest on some underlying authority, either statutory or constitutional. For example, neither the Constitution nor any statute authorizes any corrupt promise to limit discretion. Thus, a promise to limit discretion that is not induced by the Attorney General's appraisal of the best interests of the United States, but by a bribe or other inappropriate appeal to self-interest, is an impermissible basis for settlement.

It seems likely, moreover, that the constitutional bar to "high crimes and misdemeanors" is not the only limit on permissible promises to bind discretion. Congress has confined the Attorney General's statutory authority to conduct litigation to the broadest of standards: that the Attorney General "attend to the interests of the United States." On the basis of this mandate, Attorneys General have repeatedly referred to their settlement authority as "plenary." Yet, even the "plenary" authorities of the United States $\boldsymbol{*} \mathbf{2 5 5}$ are presumptively subject to the limiting principles of the Constitution.

In order to ascertain the precise contours of executive authority to limit the revisability of executive discretion, it is helpful to distinguish discretion that is vested in the executive by the Constitution from discretion that is vested by statute. This distinction is helpful because the source of the executive discretion at issue corresponds to the source of any legal constraint that operates on executive authority to limit that discretion. Any constraints on executive authority to limit discretion that has been vested in the President by the Constitution will themselves be based in the Constitution. As far as I know, Congress has passed no statute addressing the President's power to compromise his own constitutionally based discretion.

On the other hand, constraints on executive authority to limit discretion that has been vested in the executive by statute are themselves essentially statutory and must be determined with reference to legislative intent. The discretion subject to limitation is discretion delegated by Congress, at its discretion. Whether the President may compromise discretion Congress has so vested is likewise a matter within Congress's power to decide.

1. Executive Authority to Limit Constitutionally Vested Executive Discretion. Much of the discretion vested in the President directly by the Constitution is critical to the successful operation of the government as the Constitution envisions it. For example, the President's authority to disapprove legislation under Article I, Section 7, is obviously of central importance to the system of checks and balances in the legislative process erected by the Constitution. Thus, any purported 
promise, say, not to veto any environmental protection bill voted by Congress during the next five years could not have legal force. It would represent an abdication ${ }^{*} \mathbf{2 5 6}$ of a nondelegable constitutional function, and thus a void promise.

Similarly, the President's authority to pardon offenses against the United States is an express check on the judiciary. A purported promise, say, not to pardon any person convicted of a criminal civil rights offense during the next five years would likewise be void.

These examples suggest that any executive promise to render constitutionally based discretion less revisable under a consent decree should be void and unenforceable. Such a doctrine would provide a bright line substantive limitation on discretion-binding consent decrees, and the executive has, in fact, advanced this position in litigation.

A familiar counterexample, however, suggests that such a doctrine would be too restrictive of the President's authority to render his discretion less revisable. The example is the practice of promising nonprosecution on particular criminal charges to individuals who agree (a) to plead guilty to lesser charges, or (b) to cooperate with the prosecution of others. Such promises are enforceable, although they preclude the future exercise of ordinary prosecutorial discretion to charge persons with criminal offenses.

The executive branch is authorized to limit its constitutionally based prosecutorial discretion in this way because the exercise of current executive discretion to confine future executive discretion over prosecution can be justified in particular cases by a sufficiently weighty public interest in law enforcement. Such an im- plicit *257 balancing judgment is consistent with the Supreme Court's balancing approach generally to separation of powers questions not addressed explicity by the constitutional text. The Court has said:

[I]n determining whether [an act of one branch] disrupts the proper balance between the coordinate branches, the proper inquiry focuses on the extent to which it prevents [one branch] from accomplishing its constitutionally assigned functions. Only where the potential for disruption *258 is present must we then determine whether that impact is justified by an overriding need to promote objectives within the constitutional authority [of the acting branch].

Presumably, the limits on any branch's authority to interfere with its own assigned tasks should be assessed under a functional test similar to this test for interbranch disputes. Under this reasoning, an executive promise to render its discretion less revisable would not be unconstitutional if (a) such a promise did not prevent the executive from accomplishing its constitutionally assigned functions, or (b) if such a promise were justified by an overriding need to promote objectives within the constitutional authority of the executive. Whether a consent decree promise binding future executive discretion prevents the executive branch from accomplishing its constitutional functions is likely to turn on two factors. The first is the degree to which the ordinary revisability of executive discretion on the question involved is essential to the constitutional checks and balances. For example, the insertion of the President into the legislative process via the veto mechanism was so critical an aspect of the framers' design that any enforceable promise to veto or not to veto particular legislation arguably should be regarded as a per se disruption of the executive's responsibilities. The second factor is the degree of freedom the 
executive has, through a modification of a consent decree, to renege on a discretion-binding promise it has made in that decree. For example, if the executive were entitled to a modification of a promise concerning the future exercise of constitutionally based discretion whenever it could articulate to a court a substantial reason for regarding the modification as necessary to the exercise of a constitutional obligation, then the promise itself would not significantly disrupt the executive's assigned duties.

So permissive a standard for decree modification would be a departure from current law. The ordinary precondition for obtaining a modification over the objections of the other party to a consent decree is that the party seeking the modification demonstrate a change of circumstances rendering enforcement of the original decree a serious injustice. Under this standard, the executive would likely argue that any promise rendering constitution-ally $* \mathbf{2 5 9}$ based discretion less revisable disrupts the executive's discharge of its constitutional functions, and should be presumed a "serious injustice" on its face. Even if a court were to accept that presumption as its starting point, however, its determination of whether a "serious injustice" is actually presented is likely to turn on the second prong of the Supreme Court's separation of powers inquiry--the weightiness of the public interest proffered to justify the executive's original discretion-limiting promise.

In United States v. Board of Education of the City of Chicago, the executive made a discretion-binding promise that required justification on this basis. As recounted above, the United States, after suing the Chicago Board of Education to require the desegregation of Chicago schools, made a "best efforts" promise to assist in desegregation funding, as part of the consent decree settling that suit. The Board of Education argued, and a district court held, that the "best efforts" promise constituted a pledge that the President would not exercise his authority "to recommend [to Congress] such measures as he shall judge necessary and expedient" in a way that would impede federal funding of Chicago's school desegregation effort. Although the Court of Appeals ruled that the consent decree in fact made no commitment with respect to the President's powers of legislative recommendation, it is worthwhile to consider whether it would have been constitutional for the Attorney General to promise expressly, "[t]he executive shall not sponsor legislation rendering the implementation of the decree impracticable.”

Assuming that such a promise would inhibit the executive in the performance of constitutionally assigned functions, a strong $* \mathbf{2 6 0}$ case can be made that overriding interests justify the promise. The promise could be viewed as furthering the executive's obligation to take care that the laws be faithfully executed by helping to insure the effective vindication of the rights of Chicago school children to nondiscriminatory treatment under Title VI of the Civil Rights Act of 1964. It could also be viewed as furthering the Attorney General's statutory obligation to attend to the interests of the United States by avoiding the extraordinary effort and expense of a trial. Indeed, the avoidance of trial would likely be a significant contribution itself to the vindication of the schoolchildren's rights, because effective desegregation is far more likely when undertaken with the initiative and cooperation of responsible school authorities. Whether such an argument would persuade a court of the enforceability of the hypothetical promise is uncertain; but the argument is persuasive, partly because of the public interests involved and partly because the interference with executive responsibilities is limited. 
It is in any event fairly easy to avoid constitutional problems with consent decrees that limit the future exercise of constitutionally based executive discretion. Any consent decree that makes a promise constraining the future exercise of constitutionally based discretion entered in settlement of a suit in which the United States is a defendant, could provide: "The sole remedy for the department's *261 or agency's failure to comply with [the relevant terms of the settlement agreement] shall be the revival of the suit." Any such consent decree entered in settlement of a suit in which the United States is the plaintiff could provide a similar limitation on enforcement, such as: "The United States shall not be deemed in violation of this decree because of the exercise of policymaking discretion vested in the executive by the Constitution, including discretion to sponsor, oppose, or refrain from sponsoring or opposing any federal legislation or appropriation.” Were a consent decree to contain this language, there could be no enforcement of the executive's promise in a manner disruptive of the President's constitutional functions even if the executive could not persuade a court to approve a modification of its obligations.

2. Executive Authority to Limit Discretion Vested by Statute. The discretion-binding promises that appear in consent decrees are more likely to involve the exercise of statutory, rather than constitutional, discretion. That is because lawsuits concerning the discretionary decision making of the United States typically involve areas where the executive's entire decision-making authority comes from Congress, that is, cases of domestic peacetime social and economic regulation. As explained above, the scope of executive power to render executive statutory discretion less revisable than it would otherwise be must be determined with primary reference to statutory law, not the Constitution.

There are several ways in which a consent decree designed to enforce an agency's statutory obligation to regulate in a particular area might appear to render less revisable certain statutory discretion vested in the agency. The most obvious example would be an agreement to promulgate a regulation as required by statute. Outside the litigation context, the Administrative Procedure Act ordinarily permits an agency that has promulgated a rule to rescind or amend the rule so long as it can proffer a reasoned basis for doing so. Unless a consent decree promising to issue a rule expressly reserved that amendatory discretion, however, the agency's authority to amend any rule promulgated pursuant to the decree might depend on its ability to secure a modification of the decree. A motion for modification is an appeal to the discretion of $* \mathbf{2 6 2}$ the court and, as noted above, the moving party is ordinarily entitled to a modification only when the consent decree no longer conforms to the applicable law or when continued implementation of the unamended decree would amount to a "grievous wrong." It is not at all clear that the existence of a reasoned basis sufficient to justify an amended rule outside the litigation context would entitle justify an amended rule outside the litigation context would entitle the agency as a matter of law to a modification of the decree to permit that same amendment.

That being so, an agency willing to proffer a new rule in settlement of a lawsuit must consider what it wants to do about its amendatory power. One strategy would simply be to insist that the agency's discretion under the consent decree be no less revisable than its ordinary rulemaking discretion. For example, the decree might provide: "The agency shall possess discretion to amend any rule promulgated pursuant to this decree that is equivalent to its ordinary legal discretion to amend or rescind agency rules." Any decree that so protects the agency avoids the 
issue of whether the agency can agree to constrain its discretion and it leaves the revisability of the agency's discretion unimpaired.

In some cases, however, that strategy may be impracticable. Consider, for example, EPA's settlement promise to investigate specified industries not mentioned in the Federal Water Pollution Control Act for possible toxic pollution regulation. Ordinarily, a decision to investigate a particular respondent in a regulatory context is left to the unreviewable discretion of an administrative agency. The only way that EPA could promise to investigate particular industries and still retain its ordinary discretion not to investigate those industries would be to provide that its commitment in this respect was absolutely unenforceable. It would be an odd plaintiff who would be willing to settle a lawsuit in return for such a promise. Thus, in order to obtain settlement in a lawsuit challenging agency nonenforcement of a statute, an agency usually has to limit its discretion to some degree.

No federal statute, however, squarely authorizes or prohibits discretion-binding agreements of this sort. An agency's authority to constrain its discretion beyond those limits imposed by a regulatory statute itself would have to be derived by implication. Whether such authority can be inferred from the regulatory statute at issue, the Administrative Procedure Act, or the authority of $* \mathbf{2 6 3}$ the Attorney General to attend to the interests of the United States in litigation raises a classic Youngstown-type problem: how to determine the scope of executive statutory authority in the absence of any statutory language expressly permitting or prohibiting the contemplated executive initiative.

It is fair to say that the executive would not have authority to promise to exercise its administrative discretion in contravention of a regulatory statute. Thus, for example, if a statute prescribes ten exclusive decision-making criteria with respect to a particular regulatory decision, the implementing agency could not promise to be bound by an eleventh unnamed factor or to ignore one of the ten. Even if such a promise were plausibly in the interest of the United States as a matter of policy, the Attorney General would presumably lack the authority to make it in the face of a specific congressional determination that a different regulatory strategy was in the interest of the United States as a matter of law.

Such promises are unlikely, however. What is much more likely is a proffered plan of statutory implementation that (a) is reasonably consistent with the underlying regulatory statute, (b) is reasonably proffered in settlement as being in the interest of the United States, but (c) imposes greater constraints on the discretion of the agency than are imposed by the regulatory statute itself. *264 Divining congressional "intent” with respect to such a discretionary decision-that is, a discretionary decision to constrain future regulatory discretion--involves a sensible imputation of congressional purpose in light of a careful assessment of the reasonableness of the agency's promise.

The Supreme Court has held that, outside the context of litigation, agencies with general regulatory authority may impose on themselves procedural requirements going beyond the minimal requirements of the Administrative Procedure Act (“APA”) or the specific substantive statute being implemented. An agency, for example, that is authorized to adopt a regulatory policy through informal APA rule making would be authorized to decide, on its own initiative, to 
determine that policy entirely based on a publicly disclosed rule-making docket--a discretionconstraining device not ordinarily required in informal rule making. Presumably, the inference that agencies enjoy such authority is based on the premise that an expert agency might rationally conclude that procedural requirements going beyond minimal statutory mandates would result in a sounder or more effective implementation of the agency's substantive obligations. If Congress is deemed to have authorized agencies generally to impose on themselves procedural requirements going beyond explicit statutory minima, it is hard to see why Congress should not be deemed to have granted power to make similar decisions in settlement of litigation when those decisions would likewise implement the agency's obligations and protect the interests of the United States in litigation.

This analysis, however, requires that the agency make a conscientious assessment of the reasonableness of its promise. A promise to maintain a particular rule in place subject to future amendatory rule makings on an exclusive public rule-making docket seems a fairly narrow intrusion into the agency's ordinary amendatory discretion and facially unobjectionable, no matter what the substantive statute at issue. Similarly, a nonrevisable promise to investigate particular industries as part of a regulatory effort might be viewed as acceptable because it does not directly infringe on the agency's discretion to make substantive policy or require even that a regulation ultimately issue. On the other hand, a promise to maintain a rule in place for ten years absent "exigent circum- stances" *265 or a "national emergency" would appear such a bizarre departure from ordinary administrative procedure--a procedure that Congress has never adopted for any regulation whatsoever--that authority to make such a promise could not reasonably be implied merely from a general authorizing statute and the Attorney General's broad authority to conduct litigation. Even if such a promise might be regarded in some circumstances as reasonably in the interests of the United States, both its novelty and the extremity of its intrusion into ordinarily revisable agency discretion should be deemed to render it unreasonable without clear congressional authorization.

3. Summary. The foregoing discussion can be distilled into a set of general principles regarding executive authority to render ordinarily revisable discretionary executive decisions into less revisable discretionary executive decisions through the medium of an enforceable settlement agreement.

First, the executive lacks authority to make promises to bind its future discretion: (a) when the discretion involved is constitutionally vested, and a promise to render such discretion less revisable cannot be justified by an overriding public interest within the constitutional authority of the executive to protect; or (b) when the discretion involved is statutorily vested, and a promise to render such discretion less revisable is in contravention of statute or cannot reasonably be regarded as within Congress's authorization. A promise to render statutory discretion less revisable should be regarded as implicitly authorized if the promise is (1) a reasonable means of implementing the underlying regulatory statute, and (2) reasonably in the interests of the United States in litigation.

Second, in any suit in which the United States is unable to promise legally to render its policy-making discretion less revisable, it may still make discretion-related promises a part of a consent decree and avoid constitutional problems through proper drafting of the decree. If the United States is the defendant, it may avoid constitutional problems by conditioning any promise 
to exercise discretion on behalf of the plaintiff on the retention by the United States of the ordinary revisability of its discretion. In any case in which the United States is the plaintiff, it may avoid constitutional problems by conditioning a promise to exercise discretion on behalf of the defendant on an understanding that the promise is unenforceable, or unenforceable through any order that constrains the United States in the exercise of its discretionary decision making.

*266 B. Judicial Authority to Approve Constraints on Executive Discretion

The entry of a consent decree binding the United States implicates not only the authority of the executive, but the authority of a court as well. Once the problem of executive authority is solved, however, the problem of judicial authority poses no further obstacles because a court may approve any consent decree that embodies a discretion-constraining promise that the United States is legally authorized to make.

The Justice Department does not share this view and has argued, most vigorously in the affirmative action context, that courts approving consent decrees are limited to approving remedial measures that could have been imposed on the consenting defendants after trial. Specifically, the Justice Department has repeatedly urged federal courts not to approve voluntary race-conscious remedial measures that go beyond such race-conscious measures as a court might impose on a defendant found liable for discrimination under Title VII of the Civil Rights Act of 1964. The Department draws its strongest support for this position from Firefighters v. Stotts, the muchpublicized case involving minority layoffs in the Memphis Fire Department.

*267 When the Supreme Court in 1986, in Local Number 93 v. City of Cleveland, considered the scope of a federal court's authority to approve remedial measures agreed to in a consent decree, six Justices emphatically rejected the Justice Department's position. The Court held that the boundaries of permissible agreement between consenting parties were set by their legal authority to enter into the promises made, not by the court's authority to impose remedies after trial:

[I]n addition to the law which forms the basis of the claim, the parties' consent animates the legal force of a consent decree. Therefore, a federal court is not necessarily barred from entering a consent decree merely because the decree provides broader relief than the court could have awarded after a trial.

This is not to say that the parties may agree to take action that conflicts with or violates the statute upon which the complaint was based . . . [T] he fact that the parties have consented to the relief contained in a decree does not render their action immune from attack on the ground that it violates [ [ [the federal statute underlying the claim] or the Constitution. However, . . . to the extent the consent decree is not otherwise shown to be unlawful, the court is not barred from entering a consent decree merely because it might lack authority . . . to do so after a trial.

Under this analysis, the limits on judicial power to approve a discretion-limiting consent decree involving a federal agency derive not from the court's remedial authority, but from limits 
on the agency's legal authority to constrain its own discretion. Any promise an agency is empowered to make, a court is empowered to approve as part of a consent decree.

This is all the more sensible if one reflects on the role of a court after a trial that the agency loses. Once an agency is found liable for its failure to implement a statute properly, a federal court is not ordinarily empowered to direct the way in which the agency's discretion is to be exercised in fulfilling its statutory obligations. A court may, however, demand a proposed plan of compliance or issue declaratory relief and retain jurisdiction to insure $* \mathbf{2 6 8}$ that the agency subsequently exercises its discretion in a manner that affords the plaintiffs relief. In any such case, the court that reviews agency compliance under a judgment is essentially in the same position it faces when reviewing an agency's proffered consent decree: its task is to determine whether the agency's chosen means of statutory implementation reasonably fulfills its legal mandate.

The only substantial legal difference between the role of a court reviewing a proposed consent decree and its role after trial is that the court derives its review authority in the consent decree situation from the parties' consent, and in the post-trial context from the adjudication of agency liability. In either case the prospect exists for limited judicial supervision of agency policy making. Thus, in order for the Justice Department's position to be sustained, the fact that the source of a court's remedial authority differs in the consent decree and post-trial contexts would have to imply that consent cannot yield remedial authority as extensive as adjudication. In other words, in the Justice Department's view, a determination of liability would have to precede judicial involvement in the settlement of any statutory case in which fulfillment of the agency's statutory mandate ordinarily contemplates some exercise of policy-making discretion; only a finding of a legal violation would authorize supervisory judicial remedies. There is no apparent functional justification for such a position, however. It is belied by the obvious value of consent decrees to the federal government in the conservation of time and legal resources.

Although separation of powers principles do not limit judicial authority to approve consent decrees embodying lawful executive promises, they should play a role in the enforcement of the decree. This is true with respect to the interpretation of decrees, entertaining requests for modification, and enforcing decrees in the face of executive noncompliance.

First, in interpreting a consent decree, courts should be reluctant to conclude that an agency has promised to render its admin- istrative $\boldsymbol{*} \mathbf{2 6 9}$ discretion less revisable. Where Congress has vested largely revisable discretion in an agency, preserving that discretion ordinarily furthers Congress's policy intentions. Congress may license departures from the revisability of discretion where a settlement on such terms reasonably implements the governing statute and is otherwise in the interest of the United States. A court should conclude that an agency has made such judgments, however, only if the decree's language or extrinsic evidence demonstrates that the agency made those determinations on a reasoned basis.

Second, a court should respect the separation of powers in reviewing requests for modification of a consent decree. This means at least that, in reviewing a private party's proposals for the modification of a decree over United States objections, a court should not ordinarily impose modifications that go farther than the original decree or the underlying law in constraining agency policy-making discretion. A more complex question is whether, in reviewing executive proposals 
for the modification of a discretion-limiting decree over a private party's objections, a court should apply a lesser standard than applies to the review of modification requests in the ordinary consent decree case. A flexible standard for modification of "consistency with the public interest and the original purposes of the consent decree" would better take account of the ordinary revisability of an agency's discretion, and might prevent consent decrees entered into by one administration from excessively constraining the policy choices of another. This standard is in keeping with recommendations that have already been suggested for litigation aimed at other forms of institutional reform. On the other hand, adoption of a lenient modification standard might inhibit other parties from settling with the government because it would reduce the reliability of the government's settle-ment $* \mathbf{2 7 0}$ promises. As noted earlier, any such move in the name of protecting future discretion would limit the executive's present discretion to settle lawsuits as it deems appropriate.

Finally, in enforcing a decree against an agency, courts should try to avoid remedial steps that unduly control an agency's exercise of discretion. If a court finds it necessary to enforce a decree through additional injunctive or declaratory relief, the court should go no further in specifying subsequent agency behavior than is minimally necessary to afford a reasonable prospect of ultimate agency compliance. Courts should indulge, absent compelling contrary indications, a presumption of executive good faith in responding to judicial orders, whether in the consent decree or post-trial remedial context.

III. PROCEDURAL LIMITS ON DISCRETION-LIMITING CONSENT DECREES

Even if there is substantive authority for discretion-limiting consent decrees, a court and the executive must respect procedural rules in the entry of such decrees that account for their potential impact on third-party rights. The possibility of such impacts is not peculiar to discretionlimiting consent decrees. It exists with respect to all settlements and, indeed, with respect to litigation generally. In all settings, litigants are bound by rules that limit the legal impact of judgments on unrepresented third parties and rules that facilitate representation, for example, through notice and the prospect of intervention.

Because the mechanisms for third-party protection are so thoroughly discussed elsewhere, I do not want to dwell on their details here. Instead, I would like to focus on the particular ways in which third-party rights are likely to be affected by discretion-limiting consent decrees, and suggest in a general way the kinds of procedural responses that are most likely to be useful in protecting third-party interests. The three key sources of danger to these interests in the process of settlement are lack of representation, lack of adversariness between the settling parties, and a lack of regard for principle in the formulation of a decree.

*271 A. Lack of Representation

Settlement negotiations are typically conducted in unpublicized, secret meetings among a limited number of parties. Interests importantly affected by particular litigation may thus go unrepresented and particular, difficult-to-organize constituencies may never achieve effective participation.

Whether the lack of representation for third-party interests calls for any systematic corrective in suits involving the exercise of administrative discretion is difficult to assess without more data as to the actual pattern of settlement behavior among administrative agencies. Often, 
such exclusion is not a real problem. For example, although settlement negotiations may go unpublicized, organized interests affected by the regulatory activity of a particular agency may be engaged in such thorough and routine monitoring of the agency's activities that the facts of ongoing litigation and prospective settlement are well-known to the relevant community. Such actual knowledge may be sufficient to assure that such persons or groups potentially affected by settlement can take timely advantage of the opportunity to intervene in the litigation. Unorganized interests may still go unrepresented, but it is an open question whether they would be any more represented at the remedial stage of an adjudicated lawsuit. It is equally uncertain whether they would be any better represented if the decisions being made in the context of settlement were being made in Congress or by the agency through ordinary administrative processes.

The interests of non-negotiators are further protected by rules that require notice of settlement in particular cases or that limit the legal impact a settlement may have on any person who was not party to the settlement. Class actions against administrative agencies may not be settled, for example, without notice to all class members. Moreover, settlements in particular classes of cases may proceed, under statute or regulation, only pursuant to public notice published in the Federal Register.

*272 The nature of a settlement also may mitigate the impact of third-party exclusion. If an agency, pursuant to a settlement agreement, promises only to issue a notice of proposed rule making on a particular subject, persons who did not participate in the negotiation of that promise may comment on the proposed rule. Thus, they will not be wholly excluded from the substance of agency decision making on the question at issue.

Still, mere recitation of the factors potentially mitigating the problems of lack of representation is hardly sufficient to eliminate these problems completely. The potential social impact of lawsuits concerning the exercise of agency discretion is often great, as is illustrated by the cases discussed above on the regulation of environmental toxics, school desegregation, and housing assistance for poor people. Further, the cost of providing general notice of proposed settlement through the Federal Register is small. It is likely, therefore, that public notice would be salutary with regard to discretion-limiting consent decrees or, at least, with regard to some particular subset of such settlements--for example, settlements contemplating the issuance of proposed rules, either generally or in particular subject matter areas.

Whether further steps are necessary to avoid the exclusion of difficult-to-organize interests requires additional study. Perhaps agencies should be required to undertake some initiative to assure representation for interests shared by an otherwise unorganized constituency. To sustain any such proposal, however, it would be helpful to have a much clearer picture as to how many settlements are likely involved and whether exclusion is a genuine problem in such suits.

B. Lack of Adversariness Between Settling Parties

Non-adversary settlements can also compromise third-party interests. For example, an agency's settlement may be shaped more by the agency's internal political agenda or by its responsiveness to an ongoing relationship with the suing party or parties than by a faithful, disinterested assessment of the most appropriate implementation of its statutory responsibilities. That is, the agency $* \mathbf{2 7 3}$ may be motivated by factors other than those Congress has deemed to be 
in the public interest. The now-venerable shorthand phrase for the latter phenomenon is "agency capture.”

It is by no means unthinkable that an administrative agency might find a consent decree a useful device for "binding" itself to something it wants to do anyway, perhaps to avoid conspicuous responsibility for an unpopular policy initiative, to prevent a change of policy by a subsequent administration, or as leverage in interand intra-branch negotiations over budgeting. Where the proposed settlement is substantively authorized, however, it will be difficult to smoke out such cases. The best courts could do in reviewing consent decrees would be to require statements, akin to the statements of basis and purpose that must accompany agency rules, as to why an agency regards a consent decree as an appropriate means of statutory implementation and otherwise in the interests of the United States in litigation. The articulation of such an analysis cannot assure that other motivations animating the consent decree are absent. Yet, more intrusive judicial attempts to police the agency's willingness to settle litigation would themselves represent questionable intrusion in the agency's discretionary policy making.

Perhaps it is heartening in this respect that the risk of agency capture, as an impetus for collusion or half-hearted bargaining, does not appear very great with respect to many of the lawsuits that have produced discretion-limiting consent decrees. As others have observed, the possibilities of agency capture antithetical to the public interest are greatest when the only organized actors are the agency and the regulatees. Accusations of agency capture are most credible with respect to the economic regulatory agencies, such as the ICC or FCC, which regulate on an industry-by-industry basis. It is of considerable significance not only that the agency might be staffed by former industry personnel or might actually depend on industry lobbyists for information, but also that these agencies' statutory mandates are often so broad as to provide little *274 statutory counterweight to industry demands for understanding and accommodation.

Social regulatory agencies such as OSHA or the EPA, on the other hand, police problems such as workplace hazards or pollution, not individual industries. Further, the policies behind these agencies' statutory authorizations are typically more focused in the relevant statutes and often embodied in more precise commands. These factors--coupled with the organization over the last fifteen to twenty years of public interest groups shaped to defend the policies underlying regulatory statutes--create a much lesser risk of agency capture. The pattern of ongoing informal relationships for such agencies is typically triangular--agency, public interest groups, and regulatees. With respect to agency capture:

Tripartite continuing relationships have precisely the opposite effect of two-party arrangements. Instead of promoting informality, when a third-party group sets out to monitor agency-clientele relations, systematic pressures towards formality and "going by the book" are created.

Indeed, there seems to be some substantial sentiment within the administrative law community that some administrative programs could be better conducted under a regime of cooperative decision making by an agency and the parties with whom the agency has an ongoing relationship. If the risk of agency capture in unsupervised policy making itself seems reduced 
these days, the risk of collusive settlements--which occur at least under the nominal supervision of a court--seems a fortiori to be of even lesser concern.C. Lack of Attention to Principle

"Negotiation,” as Professor Melvin Eisenberg has written, “is conventionally perceived as a relatively norm-free process centered on the transmutation of underlying bargaining strength into agree- ment $* 275$ by the exercise of power, horse-trading, threat and bluff.” By contrast, "[a] djudication is conventionally perceived as a normbound process centered on the establishment of facts and the determination and application of principles, rules, and precedents." To the extent these perceptions are accurate, lawmaking by settlement is even more dangerous to third parties than law-making by litigation pressed to judgment, even though only a few of the affected interests may be represented in either case.

There is, however, as Professor Eisenberg details, good reason to doubt the starkness of this comparison between negotiation and adjudication. Negotiations over settling disputes that arise from past events typically do invoke principles, rules, and precedents. The chief difference is that the lesser formality of negotiation may broaden the universe of acceptably relevant norms and the options for accommodating a broad range of interests in the form of a settlement. This is less true in negotiations over the future behavior of some party--an administrative agency, for example--but only if one party has an alternative to negotiation, such as buying a desired good from a different seller, that obviates any sensitivity on its part to considerations other than sheer bargaining power.

Applying these insights to administrative law litigation, it is difficult to diagnose any risk of unprincipled settlements that justifies the adoption of special prophylactic rules governing executive settlements. To the extent there is an imbalance in bargaining power in suits brought by individuals, it may well be the Justice Department, not the private plaintiff, who has greater resources for the maintenance of litigation. As between the Justice Department and organized plaintiffs--whether advocates for private industry, organized labor or a public interest group-litigating power is probably balanced sufficiently to make disparate resources a fairly inconsequential determinant of the shape of final settlement. To $* 276$ the extent the shadow of litigation exerts a force over settlement negotiations, it is just as likely that the parties' respective estimates of likely success will determine their behavior as that the cost of litigation will do so. And these estimates, of course, are going to be based substantially "on the establishment of facts and the determination and application of principles, rules, and precedents" that is ideally characteristic of adjudication.

$* * *$

In sum, the process of lawmaking by consent decree would likely be more protective of third-party rights, and at little cost, if notices of proposed settlements, at least in certain classes of important cases, were published in the Federal Register and if agencies were required to provide statements defending proposed consent decrees as rational means of implementing their responsibilities and protecting the interests of the United States in litigation. Additionally, it might prove appropriate on further study to require agencies to undertake some initiative to assure representation in the settlement process for interests shared by an otherwise unorganized constituency. My own conclusion, however, is that the risks to third-party rights from lack of representation, a lack of adversariness between the settling parties, or inattention to matters of 
principle in the settlement process are not so great as to require more drastic protections from consent decrees than from other settlements or judgments that potentially affect such third-party rights.

IV. DISCRETION-LIMITING CONSENT DECREES AND THE IDEOLOGY OF PUBLIC LAW

Perhaps the most strenuous criticisms of discretion-limiting decrees focus not on their legality, but on their appropriateness as a matter of policy. Even if such decrees are lawful, executive resort to their use is itself discretionary. Thus, executive participation in the decrees appears to be a policy endorsement of lawmaking by settlement generally, and a ratification specifically of policy making by a kind of settlement that legitimates some degree of judicial supervision of agency policy making.

A dramatic example of a policy-oriented attack on lawmaking by settlement generally is Professor Fiss's denunciation of consent $* 277$ decrees in public litigation as privatized lawmaking. In Professor Fiss's view, advocates of settlement make "settlement appear as a perfect substitute for judgment . . . by trivializing the remedial dimensions of a lawsuit, and also by reducing the social function of the lawsuit to one of resolving private disputes. ..." Fiss argues, in contrast:

[T] he purpose of adjudication should be understood in broader terms. Adjudication uses public resources, and employs ... public officials ... [ [ [who] possess a power that has been defined and conferred by public law, not by private agreement. Their job is not to maximize the ends of private parties, nor simply to secure the peace, but to explicate and give force to the values embodied in authoritative texts such as the Constitution and statutes: to interpret those values and to bring reality into accord with them. This duty is not discharged when the parties settle.

It is of critical concern to Professor Fiss that settlements, because they rest on consent, do not "contain the kind of enforcement commitment" implicit in a post-trial judgment. Even where the settlement appears in a consent decree, enforcement is impeded because the absence of a trial leaves the judge relatively ignorant of the background necessary to determine the sufficiency of performance under the decree, and because courts are often reluctant to use performance-oriented remedies against high officials to enforce essentially contractual obligations. If administrative lawmaking consisted only of consent decrees or other settlement agreements, I could more readily understand Professor Fiss's concern. Regulatory law, however, does not consist even nearly of settlements alone. Not only do many major disputes proceed to a final contested judgment, but congressional hearings and administrative procedures, both rule makings and adjudications, provide frequent occasions for the elaboration and vindication of public values. The legislative and executive branches are no less public institutions than courts. It is thus difficult to share Professor Fiss's concern that society is foregoing, in the name of expe- dient $* 278$ settlements, its genuine need for authoritative interpretations of administrative law through public processes.

In contrast to Professor Fiss's general antipathy to settlement, the Justice Department has expressed a specific hostility to discretion-limiting consent decrees. This hostility is part and parcel of a broad Reagan Administration attempt to revive and give new life to a "categorical" model of the separation of powers, in which a fundamental aim of public administration is to confine Congress, the executive, and the courts, respectively, to three categories of tasks--making, 
implementing, and interpreting law. Although the Administration's advocacy of this model has met with recent success in the Supreme Court, the categorical model runs against the grain of recent Supreme Court opinions that take a functional view of the separation of powers.

*279 As part of its campaign on behalf of the separation of powers, the Justice Department, in March 1986, issued a series of “policy Guidelines” concerning consent decrees and settlement agreements. In essence, they direct Justice Department lawyers not to consent, in the settlement of litigation, to commitments that limit otherwise revisable policy-making discretion vested in the executive branch by Constitution or statute. The proffered aim of these Guidelines is "to preserve the constitutional prerogatives of the $\boldsymbol{*} \mathbf{2 8 0}$ President and other officers of the Executive Branch, including their policy-making discretion." Without elaboration, the covering memorandum describes the Guidelines as "significant expressions of our view of the Constitution.”

Given the significance that the Department attributed to the Guidelines and the Guidelines' purpose "to guide government attorneys involved in the negotiation of consent decrees and settlements," it seems odd that they were not drafted with greater apparent care. The Guidelines include three directives for "consent decrees" and three directives for "settlement agreements" that affect agency discretion in rule making, management, and budgeting. Yet the precise intent of each directive is obscured both by the inartful phrasing of the Guidelines and the lack of a clear explication of the legal theory that underlies them.

A threshold source of confusion is the preamble's unexplained assertion that separation of powers principles importantly limit the appropriate use of consent decrees in litigation, but "settlement agreements--similar in form to consent decrees, but not entered as a order of the court-remain a perfectly permissible device for the parties and should be strongly encouraged." Why this distinction is made, given the presumable judicial enforceability of all lawful settlement agreements, is not explained.

The first directives for both consent decrees and settlement agreements concern promises regarding rule making. As to consent decrees, the Guidelines state:

*281 The department or agency should not enter into a consent decree that converts into a mandatory duty the otherwise discretionary authority of the Secretary or agency administrator to revise, amend, or promulgate regulations.

As to settlement agreements, the Guidelines state:

The department or agency should not enter into a settlement agreement that interferes with the Secretary or agency administrator's authority to revise, amend, or promulgate regulations through the procedures set forth in the Administrative Procedure Act.

The variations in the underlined phrases in these two directives raise a number of problems. To illustrate an important one, imagine a plaintiff public interest group suing to require EPA to perform its statutory obligation to protect against a particular pollutant. EPA might contemplate promising to promulgate a rule (as required by statute), and further promise that the rule would remain in force for five years, absent "exigent circumstances” requiring a new rule making. The 
latter promise would seem to "interfere with" the EPA Administrator's authority to "amend ... regulations," and, therefore, could not be the subject of a settlement agreement. On the other hand, it would not "convert into a mandatory duty the otherwise discretionary authority of the Secretary or agency administrator to revise [or] amend" the regulation. Thus, it would seem to follow that such a promise could be embodied in a consent decree. This appears contrary to the general premises of the Guidelines as expressed in the preamble. The second directives for consent decrees and settlement agreements pertain to budgeting discretion. As to consent decrees, the Guidelines state:

The department or agency should not enter into a consent decree that either commits the department or agency to expend funds that Congress has not appropriated and that have not been budgeted for the action in question, or commits a department or agency to seek a particular appropriation or budget authorization.

*282 As to settlement agreements:

The department or agency should not enter into a settlement agreement that commits the department or agency to expend funds that Congress has not appropriated and that have not been budgeted for the action in question.

The Attorney General's seeming concern is to prevent agencies from rendering nonrevisable their revisable discretion over budgeting and budget requests. Yet, the Attorney General oddly regards it as impermissible to promise "to seek a particular appropriation or budget authorization" as part of a consent decree, but not as part of a settlement agreement, even though the agreement is presumably an enforceable contract. Furthermore, it is seemingly only the executive branch's budgeting prerogatives, not Congress's, that are at issue. A commitment to expend funds is apparently permissible if the funds "have . . . been budgeted for the action in question," even if "Congress has not appropriated" the funds. The Guidelines are at best ambiguous on this point because it is unclear to what the word "budgeted" refers--Congress's budget or the President's. The third directives for consent decrees and settlement agreements are catchall provisions. As to consent decrees, the Guidelines state:

The department or agency should not enter into a consent decree that divests the Secretary or agency administrator, or his successors, of discretion committed to him by Congress or the Constitution where such discretionary power was granted to respond to changing circumstances, to make policy or managerial choices, or to protect the rights of third parties.

As to settlement agreements, the Guidelines state:

In any settlement agreement in which the Secretary or agency administrator agrees to exercise his discretion in a particular way, where such discretionary power was committed to him by Congress or the Constitution to respond to changing circumstances, to make policy or managerial choices, or to protect the rights of third parties, the sole remedy for the department or agency's failure to comply $\mathbf{*} \mathbf{2 8 3}$ with those terms of the settlement agreement should be the revival of the suit. 
These provisions, too, are fairly puzzling. First, they refer to discretion conferred on a Secretary or administrator "by the Constitution." It is not clear what these references mean. The Constitution confers executive authority only upon the President, who may presumably delegate it within limits. Second, the consent decree catchall guideline, but no other guideline for consent decrees or for settlement agreements, cautions against binding successors in office. Clearly, the possible (and, I suspect, unintended) implications of that reference here and its omission elsewhere are numerous.

Third, it is hard to intuit the precise contents of that category of discretion vested (by Congress or otherwise) that is intended to enable the decision maker "to respond to changing circumstances, to make policy or managerial choices, or to protect the rights of third parties." Do these criteria embrace all legally vested discretion? If not, what is omitted?

But, for purposes of separation of powers analysis, one puzzle looms overall. Lawyers may commit in settlement agreements to nonrevisable exercises of policy-making discretion, so long as "the sole remedy for the department or agency's failure to comply with those terms of the settlement agreement [shall] be the revival of the suit." It seems unquestionable, however, that the inclusion of a similar remedies-limiting provision in a consent decree would eliminate any possible separation of powers problem in that context as well. Why, then, is it not sufficient to apply the settlement agreement directive to both settlement agreements and consent decrees?

Such inartfulness in the drafting of the Guidelines obviously means that, although the Department had a theory of constitutional law it intended to express through the Guidelines, it had not worked that theory out as clearly as it should have. My intuition, however, suggests that the Guidelines have additional significance. It may be that the Guidelines were animated less by a precise legal theory than by a relatively nondiscriminating ideological stance--a *284 kind of broad policy objection to a model of judicial power that the Attorney General rejects.

The model of administrative law that I believe the Guidelines reject is well captured by Professor Stewart's seminal 1975 article on the reformation of modern administrative law and his 1982 article with Professor Sunstein on the evolution of beneficiary rights under administrative statutes. The traditional model of administrative law described by Stewart in the former article-the model the Justice Department prefers--envisioned judicial review as a bulwark against unlawful governmental intrusions into private rights of liberty or property. In contrast, the newer conception of administrative law--the conception to which the Justice Department is hostile-focuses less on protecting traditional spheres of private autonomy through bipolar litigation, than on legitimating the exercise of broad statutory power over society by reconciling, in multipolar controversies, the competing claims of government agencies, statutory beneficiaries, and regulated interests. Stewart viewed the judicial developments pointing in this newer direction as coalescing around a model of administrative law as "interest representation." Whether or not Stewart's proffered model is the only conception that captures the spirit of the modern developments he chronicles, those developments are undeniable and profoundly important for administrative agencies. Key among them are a broadening of judicially cognizable interests that may be protected $* \mathbf{2 8 5}$ through litigation, and an acceptance of the appropriateness of enforcing beneficiary claims through affirmative judicial commands to agencies. It is this latter development that the Attorney General perceives as offending the separation of powers principle. 
The development of beneficiary remedies is further elaborated by Stewart and Sunstein in their 1982 article. They explain that the recent evolution in our prevailing understanding of the purposes of administrative law has produced, as a major innovation, the acceptance of a so-called "right of initiation" against administrative agencies. Unlike the traditional private right of defense against agencies, which permits regulated parties to challenge agency action as excessive, the right of initiation permits statutory beneficiaries to challenge administrative performance as inadequate.

In some cases, the beneficiaries' claim is one precisely of initiation. For example, it may be alleged that an agency is unlawfully withholding action that is statutorily compelled or at least refraining from action for reasons that Congress has not authorized as the basis for agency policy. The claimant wants the agency to initiate action, and the agency has done nothing.

In other cases, however, the beneficiary's claim is for review of action the agency has already taken. In seeking to overturn particular regulations as abuses of discretion, the plaintiff is not seeking to initiate agency action, but to revise it. What is central to either assertion of right, however, is that the requested remedy is some form of affirmative relief against the agency--to initiate enforcement, to reconsider a policy, to conduct rule making, and so on.

As it happens, the affirmative remedies courts direct against administrative agencies are typically modest. The standard of review applied in "right of initiation" suits is usually deferential, and, even if the claimant succeeds, the resulting decree intrudes little on agency discretion. For example, a judicial determination that an agency has relied on a statutorily impermissible decision*286 making criterion results only in a remand for the decision to be made under permissible criteria. A judicial determination that an agency has improperly delayed the implementation of a policy may result ultimately only in judicial approval of an agency-proposed timetable for statutory compliance, or a judicial command to commence policy formulation by a particular date.

Yet, the supervisory nature of affirmative administrative remedies reveals a kinship between the current wave of administrative law and the more general phenomenon of "new" public law litigation in which judges are called upon to restructure public institutions to conform with broad constitutional or statutory norms. Such lawsuits, often involving schools, prisons, or mental hospitals, may have a sprawling and amorphous party structure, focus largely on "legislative"-type facts concerning institutional policy and its effects, involve intense negotiations and prolonged judicial involvement in the remedial stages, and require a more active and managerial role for the judge than is associated with many bipolar lawsuits involving traditionally conceived private rights. Challenges to this mode of litigation frequently assert a confrontation between the expansive judicial role involved and separation of powers principles--the same confrontation of which the Guidelines' preamble warns.

The Attorney General's Guidelines' expressed hostility to this "reformation of administrative law" is consistent with the view the Administration has endorsed in other contexts that the only proper federal judicial role is awarding to particular aggrieved individuals, against particular individual wrongdoers, relief that is tailored precisely to the vindication of traditionally conceived private rights. If this is the Administration's constitutional view, it is unpersuasive. It 
rests on a model of the separation of powers that the Constitution does not dictate, and it overstates the distinction between modern public law litigation and traditional judicial activity.

The hermetical separation that the Administration seems to posit between policy making, whether legislative or administrative, and judicial activity is not embodied in the Constitution. Strictly *287 speaking, it is misleading to speak of a general separation of powers as a constitutional commandment, because the principle of separation--frequently contested as to its content--is only a background understanding to the document. What the Constitution does command is an allocation of powers that seeks to foster a checking and balancing of the co-equal branches to protect us from the undue aggrandizement of federal power. The predominance of the checks and balances principle over the pure separation principle is amply demonstrated by the vesting in each branch of powers that functionally overlap with the powers assigned to the other branches. The Administration has not made any persuasive argument that modern rights of initiation in administrative law undermine the constitutional checks and balances.

Indeed, it would be hard to do so because recent administrative law decisions make clear that federal courts believe that rights of initiation are appropriate precisely because they help to protect the system of checks and balances. That is, the recognition of such rights is a judicial check to insure that the executive goes no further in the implementation of Congressionally delegated power than Congress intended. As one author has written, the animating principle of administrative law that seems most clearly to emerge from recent cases is a variant of the "traditional ... tenet that agency action is justifiable only if it remains faithful to the dictates of the legislative process." The difference in the recent cases is that the courts have realized, as Professor Sunstein puts it, that "statutes may be undermined through inaction and deregulation as well as through overzealous enforcement.” Rights of initiation *288 should, therefore, be understood as checks on usurpatious executive policy making implemented through "inaction.”

Modern implementation of this principle of fidelity to Congress does depart from some traditional views of administrative law in that (a) it both accepts and tries to legitimate the exercise of broad administrative discretion, (b) it accepts the politicization--to some degree--of agency decision making, and (c) it subordinates traditional values of private autonomy to the value of fidelity to congressional policy. Nonetheless, its animating impulse is not to supplant legislative policy making, but to reinforce it--to insure that the executive does not behave as if the Constitution, rather than Congress, is its chief source of administrative discretion in domestic policy making.

Just as the reformed model of administrative law is consistent with traditional constitutional principles, so are the forms of action evident in these cases and the limited role judges play in ordering mandatory relief consistent with traditional understandings of judicial power. It is not new for judges to implement mandatory relief to insure that inaction or resistance does not undermine the rule of law; nor is it new for judges to engage in the supervision of complex institutions. As Professors Eisenberg and Yeazell have documented, courts sometimes have engaged in these supervisory tasks without statutory imprimatur. The fact that suits involving public institutions so often have seemed "new" is not because of any historical discontinuity between the judicial role in these suits and in other, more traditional litigative contexts, but because the beneficiaries of such suits are more numerous and the substantive rights they enforce are of 
recent creation. There is simply no persuasive evidence that federal judges in "right of initiation" suits are threatening to overstep the bounds of the "judicial power" vested in the federal courts by Article III of the Constitution.

This does not prove, however, that all exercises of judicial power permissible under Article III are equally appropriate as a matter of policy. The Administration could seek, for a variety of policy reasons, to curtail judicial supervision of administrative $* \mathbf{2 8 9}$ agencies--but its appeal would have to be largely to Congress. It is Congress's substantive and procedural commands that most effectively determine the scope of judicial activity in administrative law.

For example, the Administration could seek to reduce judicial activity in some areas because the Administration is unsympathetic with the policy goals embodied in particular regulatory statutes that the courts are enforcing. Its most straightforward course would be to seek repeal of those statutes.

More modestly, the Administration could ask Congress to replace command-and-control or "action-forcing" statutes with statutes that pursue their goals through less centralized, more "reconstitutive" strategies aimed, for example, at altering market behavior. The impetus for such proposals would likely be only secondarily the desire to minimize the judicialization of administration, and primarily the conviction that such strategies could accomplish socially useful ends more efficiently. Nonetheless, such statutory changes would likely reduce the extent of judicial involvement in administration.

Perhaps most modestly, the Administration--without challenging either current statutory substance or strategy--might seek to persuade Congress to grant judicially unreviewable discretion to agencies in the implementation of administrative statutes, whatever general strategies Congress directs the agencies to employ. The Administration might argue that statutory reduction in the authorized role for judicial review would promote greater political responsiveness in the implementation of administrative statutes because judicial supervision of implementation decisions cannot help but affect their substantive content as well. Therefore, administrative statutes should be rewritten in a way that permits $* 290$ the executive maximum leeway to implement those statutes in a manner consistent with the policy implications of the most recent presidential election.

I believe that a philosophy of maximizing future presidential discretion in the implementation of administrative statutes is, in fact, a key part of the philosophy that animates the Attorney General's Guidelines. This goal is to be achieved even at the cost of reducing current discretion to settle lawsuits. As Professor McConnell's reply to this article attests, moreover, to articulate the maximization of discretion as a mere policy goal is to understate the importance the Administration attaches to it. As interpreted by Professor McConnell and, I believe, by the current Administration, the President's broad discretion to shape regulatory policy is a constitutional mandate implicit in our democratic system of government. *291 Professor McConnell and the Administration, however, virtually ignore that it is Congress, not the executive, that has primary authority for making domestic regulatory policy. The President's policy-making discretion in the such areas as the regulation of the environment, protecting occupational health and safety, and banking regulation--to name a very few of the hundreds of areas of domestic regulation--derives 
from statutory delegations. On the last day of the Reagan Administration, if Congress were to pass and President Reagan to sign an act incorporating as law all administrative regulations promulgated between 1981 and 1988, there would be no diminution in the constitutional authority of the next President--even if he were a Democrat and even if he disagreed vehemently with all such regulations. The reason we can plausibly claim to have a politically accountable government with respect to domestic regulatory policy is not, for the most part, because we vote for the President, but rather because we vote for Congress.

This article has argued for a reading of Congress's current relevant enactments that authorizes a limited role for the executive branch in constraining future administrative discretion in the context of settling litigation. If Congress does have primary authority for domestic regulatory policy, and if my statutory reading is right, then it is not a persuasive objection that the executive's exercise of its statutory discretion-limiting power undercuts any principle of electoral accountability implicit in the Constitution. It may make it more difficult to change regulatory policy simply by replacing the President; whether that is a good or a bad thing is not obvious and may well depend on the nature of the regulatory program at issue. In any event, however, Congress retains the power to vest such settlement discretion in the executive. So long as citizens may petition Congress to withdraw such authority or campaign against members of Congress who refuse to do so, all electoral accountability guaranteed by the Constitution remains intact.

Of course, even though Congress is free to respond to the full variety of possible executive recommendations for regulatory reform, it is no surprise that someone such as the Attorney General, who disfavors judicial supervision in "right of initiation" adminis- trative *292 lawsuits, will be alarmed by the phenomenon of consent decrees in such lawsuits. Such consent decrees, because of their voluntary character, would seem forcefully to help legitimate a vision of administrative law and of the courts' proper place in administration that is antithetical to a model of largely unconstrained executive discretion over the implementation of law. To issue the Guidelines in this cause, however, is, in the current legal environment, but to take "arms against a sea of troubles.” They cannot make the source of grievance--the modern regulatory state--go away.

\section{CONCLUSION}

Consent decrees that turn ordinarily revisable administrative discretion into substantially nonrevisable administrative discretion are a significant development in administrative law. Constitutional and statutory limits exist as to the kinds of promises the executive may make in a decree, although potential problems are avoidable through careful drafting. Courts may approve any promises that the executive is empowered to make, although separation of powers principles counsel sensitivity in the interpretation, modification, and enforcement of discretion-limiting decrees.

Discretion-limiting consent decrees, like all other forms of settlement or judgment, have the potential for affecting the interests of third parties unrepresented in their formulation. These interests could be additionally protected, and at little cost, if notices of proposed settlements, at least in certain classes of important cases, were published in the Federal Register and if agencies were required to provide statements defending proposed consent decrees as rational means of implementing their responsibilities and protecting the interests of the United States in litigation. 
Additionally, it might prove appropriate on further study to require agencies to help to assure representation in the settlement process for interests shared by an otherwise unorganized constituency. These reforms, together with currently existing protections for third parties, should mitigate the risk to third-party rights from lack of representation, lack of adversariness, or inattention to principle in the consent decree process.

Discretion-limiting consent decrees are important also because their existence makes a statement about our prevailing conception of public law and its purposes. Such decrees represent executive acquiescence in a form of litigation that departs from a model of judicial activity based solely on bipolar disputes over traditional private rights. For this reason, the Reagan Administration has $* 293$ launched an attack on discretion-limiting decrees. I do not share the Administration's perception that such decrees are part of an overjudicialization of administrative policy making. Nor do I share Professor Fiss's distinct concern that consent decrees contribute unduly to the privatization of our genuinely public law. The evolution of judicial law to embrace new beneficiary remedies for a broader range of substantive rights, and judicial willingness to enter consent decress implementing those rights, seem natural artifacts of the courts' faithfulness to Congress's increased concern since the late 1960s with the quality of our economic and social life.

Professor of Law, University of Iowa; A.B., Harvard, 1974; J.D., Yale, 1977. I would like to thank Randy Bezanson, Arthur Bonfield, Geoffrey Miller, David Strauss, and Peter Strauss for their helpful comments on earlier drafts, as well as Michael McConnell, both for his informal comments and for his elegant and generous formal response. I am grateful also for the research assistance of Joe Barron and Greg Schwager, Iowa '88.

National Audubon Society, Inc. v. Watt, 678 F.2d 299, 305 n.12 (D.C. Cir. 1982) (discretionlimiting decrees present "extremely interesting . . . novel, and far-reaching" issues); Alliance to End Repression v. City of Chicago, 742 F.2d 1007, 1013-14 (7th Cir. 1984) (noting possible constitutional problems raised by broad interpretation of discretion-limiting decrees). Citizens for a Better Environment v. Gorsuch, 718 F.2d 1117, 1136 (D.C. Cir. 1983) (Wilkey, J., dissenting).

See text at notes 137-181. Memorandum from the Attorney General, Department Policy Concerning Consent Decrees and Settlement Agreements (March 13, 1986), reprinted in Review of Nixon Presidential Material Access Regulations: Hearing Before the Subcomm. on Government Information, Justice and Agriculture of the House Comm. on Government Operations, 99th Cong., 2d Sess. 182 (1986), reprinted in part in 54 U.S.L.W. 2492 (April 1, 1986) ("Attorney General's Guidelines") (on file with the University of Chicago Legal Forum). These guidelines are not as precise as this discussion tries to be in explaining which consent decrees raise separation of powers or other legal questions. I try, however, to describe the problems posed in a way that is both most sensible and most consistent with the Attorney General's apparent concerns. It is not the Department of Justice's position that all consent decrees are unconstitutional: "The United States has never argued that it cannot bind itself through agreements. Nor have we ever contended that the Attorney General . . . does not have the authority to enter into binding settlement agreements, plea bargains, and consent decrees.” Reply Brief for the United States at 13, United States v. Board of Educ. of the City of Chicago, 744 F.2d 1300 (7th Cir. 1984).

For the most part, the analysis in this article of discretion that is constitutionally vested in the President does not distinguish between discretion that the executive is purposefully given and 
discretion that is the mere necessary artifact of executive obligation under the Constitution. As an example of the former, the Constitution purposefully vests plenary discretion in the President for the approval or disapproval of legislation because his exercise of broad discretion is a Constitutional "good.” It renders the intended system of checks and balances more effective.

In contrast, it is possible to speak of executive discretion vested indirectly in connection with its constitutional obligations, for example, its obligation not to inflict cruel and unusual punishment. U.S. Const. amend. VIII. Because the executive's obligation is broadly described, the President necessarily has discretion (within limits set by Congress) to determine what, specifically, he will seek to impose in federal prisons as non-cruel, non-unusual punishment. The fact that the executive possesses such discretion is not so much part of the Constitution's design, but a necessary evil; a constitution could not hope to describe specifically, for all times and all offenses, the limits of humane punishment. It is as if the Constitution instructed the President each day to sweep the White House kitchen; it would still leave discretion to decide whether a broom or vacuum, a frontto-back or side-to-side sweep would best fulfill this duty. This distinction may be significant in assessing the legitimacy of either judicial or self-imposed constraints on the President. Efforts to curtail executive discretion that is purposefully vested may undermine the intended system of checks and balances. Constraints on discretion that is merely incidental are less problematic if aimed at achieving a substantively mandated constitutional goal. U.S. Const. art. II, § 2, par. 1. Ex parte Grossman, 267 U.S. 87, 119-121 (1925); Hoffa v. Saxbe, 378 F. Supp. 1221, 1225 (D.D.C. 1974).

U.S. Const. art. II, § 3 .

Ex parte Garland, 71 U.S. 333, 380 (1866).

Marbury v. Madison, 5 U.S. 137, 162 (1803).

See FTC v. Universal-Rundle Corp., 387 U.S. 244, 249-50 (1967); Heckler v. Chaney, 470 U.S. 821, 830-32 (1985).

See, for example, Legal Aid Society of Alameda County v. Brennan, 381 F. Supp. 125 (N.D. Cal. 1974), aff'd, 608 F.2d 1319 (9th Cir. 1979) (requiring USDA officials who failed to enforce the affirmative action obligations of federal contractors with the agency to submit to the district court copies of future affirmative action plans approved by th agency, in order to permit the court to insure compliance with the agency's legal obligations).

718 F.2d 1117 (D.C. Cir. 1983). For further discussion of this case and of the role of consent decrees in environmental litigation generally, see Robert V. Percival, The Bounds of Consent: Consent Decrees, Settlements and Federal Environmental Policy Making, 1987 U. Chi. Legal F. 327, 338-40. Although Professor Percival examines the phenomenon of discretion-limiting consent decrees through a particular subject-matter perspective, readers of his essay will readily detect that his general perspective on the legality and appropriateness of such decrees is essentially the same as my own.

33 U.S.C. $\S 1251$ (1982).

Environmental Defense Fund v. Train, Civil Action No. 75-0172 (D.D.C. 1976); Citizens for a Better Environment v. Train, Civil Action No. 75-1698 (D.D.C. 1976). The cases are reported at 8 Env't Rep. Cas. (BNA) 2120.

Natural Resources Defense Council v. Train, Civil Action No. 73-2153 (D. D.C. 1976), reported at 8 Env't Rep. Cas. (BNA) 2120.

Natural Resources Defense Council v. Agee, Civil Action No. 75-1267 (D. D.C. 1976), reported at 8 Env't Rep. Cas. (BNA) 2120. 
Natural Resources Defense Council v. Costle, 12 Env't Rep. Cas. (BNA) 1833, 1834 (D.D.C. 1979).

Environmental Defense Fund, Inc. v. Costle, 636 F.2d 1229, 1235 (D.C. Cir. 1980).

Natural Resources Defense Council v. Costle, 12 Env't Rep. Cas. (BNA) 1833 (D.D.C. 1976).

Environmental Defense Fund v. Costle, 636 F.2d at 1259.

Natural Resources Defense Council v. Gorsuch, 16 Env't Rep. Cas. (BNA) 2084 (D.D.C. 1982).

Id., aff'd as Citizens for a Better Environment v. Gorsuch, 718 F.2d 1117 (D.C. Cir. 1983).

Natural Resources Defense Council, 16 Env't Rep. Cas. (BNA) at 2087; Citizens for a Better Environment, 718 F.2d at 1125-28.

Citizens for a Better Environment, 718 F.2d at 1130 (Wilkey, J., dissenting).

Id. at 1125.

Id. at 1127.

33 U.S.C. § 1316(b)(1)(A) (1982).

See cases cited in note 10 .

554 F. Supp. 912 (N.D. Ill. 1983) (approving consent decree); 567 F. Supp. 272 (N.D. Ill. 1983), aff'd in part, vacated in part, 717 F.2d 378 (7th Cir. 1983) (holding U.S. in violation of consent decree); 567 F. Supp. 290 (N.D. Ill. 1983) (upholding constitutionality of Board of Education's desegregation plan); 588 F. Supp. 132 (N.D. Ill. 1984), vacated and remanded, 744 F.2d 1300 (7th Cir. 1984) (accepting U.S. plan for compliance with consent decree and remanding for determination whether defendant receiving full entitlement of currently available funds); $\underline{610 \mathrm{~F}}$. Supp. 702 (N.D. Ill. 1985) (denying government's motion for release of sequestered funds); $621 \mathrm{~F}$. Supp. 1296 (N.D. Ill. 1985) (setting further guidelines for creating a funding arrangement under the consent decree); vacated and remanded, 799 F.2d 281 (7th Cir. 1986). For a comprehensive discussion of the litigation, see Neal Devins and James B. Stedman, New Federalism in Education: The Meaning of the Chicago School Desegregation Cases, 59 Notre Dame L. Rev. 1243 (1984).

United States v. Board of Educ. of City of Chicago, 554 F. Supp. 912, 913 (N.D. Ill. 1983).

The Associated Press, US Endorses Chicago's Proposal for Voluntary School Integration, N.Y. Times, Feb. 13, 1982, p. 1, col. 2.

Board of Educ. of City of Chicago, 588 F. Supp. at 139.

Transcript from Presidential News Conference, N.Y. Times, Jan. 30, 1981, p. 10, col. 4; Board of Educ. of City of Chicago, 567 F. Supp. at 275.

Devins and Stedman, 59 Notre Dame L. Rev. at 1254-57 (cited in note 29).

Board of Educ. of City of Chicago, 567 F. Supp. at 275-80.

Board of Educ. of City of Chicago, 717 F.2d at 381.

Board of Educ. of City of Chicago, 567 F. Supp. at 280.

Id. at 282-83.

Id.

Board of Educ. of City of Chicago, 717 F.2d at 381-82.

Id. at 383.

Id.

Board of Educ. of City of Chicago, 588 F. Supp. at 246.

Board of Educ. of City of Chicago, 744 F.2d at 1305.

588 F. Supp. at 246.

744 F.2d at 1306.

See Newport News Shipbuilding and Dry Dock Co., 55 Comp. Gen. 813, 819-21 (1976) (agencies

authorized to reprogram funds under lump sum appropriations) Memorandum Opinion for the 
Deputy Attorney General from Larry L. Simms, Deputy Assistant Attorney General, Office of Legal Counsel, re: Use of Law Enforcement Assistance Administration Program Grant Funds for Administrative Purposes, 4B Op. Off. Legal Counsel 674, 675 (June 5, 1980) (same).

743 F.2d 454 (7th Cir. 1984).

U.S. Department of Justice, Transcript of Press Conference with Charles J. Cooper, Assistant Attorney General, Office of Legal Counsel 3 (Mar. 21, 1986) (copy on file with the University of Chicago Legal Forum).

743 F.2d 454.

12 U.S.C. $\S 1701$ (1982).

Ferrell, 743 F.2d at 457.

Id.

Id. at 457-58.

If HUD had possessed discretion in 1979 to choose any of a variety of forms of mortgage relief, then a decision by HUD outside the context of litigation to adopt the assignment program would presumably have reflected an exercise of largely revisable discretion. That is, if HUD, at any later time, determined that a nonarbitrary, noncapricious rationale supported the institution of a form of foreclosure relief different from the assignment program, it could have withdrawn the assignment program and implemented a substitute. Under this scenario, HUD's agreement in 1979 to maintain an assignment program for five years would have converted the adoption of that program from an act of revisable discretion into an act of significantly less revisable discretion. Once HUD's promise was embodied in a consent decree, it could implement a substitute for the assignment program within five years only if it could persuade the court to agree to a modification of the consent decree. The existence of a merely rational basis for preferring the substitute as a matter of policy might not be sufficient to justify the modification. See United States v. Swift \& Co., 286 U.S. 106, 119 (1932) (only "clear showing of grievous wrong evoked by new and unforeseen conditions" should prompt court to modify consent decree).

Ferrell, 743 F.2d at 458.

Id.

Id. at 460 .

Id. at $463,465$.

See, for example, United States v. ITT Continental Baking Co., 420 U.S. 223, 235-37 (1975).

See Local Number 93 v. City of Cleveland, 106 S. Ct. 3063, 3077-78 (1986).

U.S. Const. art. II, $\S 4$.

28 U.S.C. $\S 518(1982)$.

38 Op. Att'y Gen. 98, 102 (1934); Attorney General's Guidelines 181 (cited in note 3).

Buckley v. Valeo, 424 U.S. 1, 134-35 (1976) (Congress's power to provide "necessary and proper" means for the selection of Federal Election Commissioners is subject to the limitations of the Article II Appointments Clause); Reid v. Convert, 354 U.S. 1, 16-17 (1957) (national power to enter into international agreements limited by provisions of the Constitution protecting individual rights); Williams v. Rhodes, 393 U.S. 23, 28-29 (1968) (state's facially unlimited constitutional power to determine the manner of selecting its presidential electors, U.S. Const. art. II, § 1, par. 2, is limited by the Equal Protection Clause of the Fourteenth Amendment).

Of course, there is a sense, if Congress has limited the President's power to compromise his statutory discretion, that there is also a constitutional limit on his discretion-limiting power: he is constitutionally bound to respect the limits that Congress has enacted. This does not add anything, however, to the search for limits on the executive power to compromise statutorily vested 
discretion. Those limits must be divined by reference to statutes, not to the constitutional command that he obey them.

U.S. Const. art. I, § 7, pars. 2-3.

See The Federalist Papers No. 74 (Hamilton) (New American Library ed. 1961) (suggesting nondelegability of pardon power); James O. Freedman, Crisis and Legitimacy: The Administrative Process and American Government 89-90 (1978) (same).

U.S. Const. art. II, § 2, par. 1.

Reply Brief for the United States at 14, Board of Educ. of the City of Chicago, 744 F.2d at 1300 (copy on file with the University of Chicago Legal Forum).

U.S. Dept. of Justice, United States Attorneys' Manual 9-27.610 (1984).

United States v. Minnesota Min. \& Mfg. Co., 551 F.2d 1106, 1112 (8th Cir. 1977) (upholding dismissal of indictment against corporation and corporate officials who provided information to United States under informal nonprosecution agreement).

See, for example, Confiscation Cases, 74 U.S. 454 (1868); Smith v. United States, 375 F.2d 243 (5th Cir. 1967).

At the University of Chicago Legal Forum symposium held on November 15, 1986, some commentators suggested that executive discretion to enter informal, binding nonprosecution agreements could be explained under two alternative rationales that would not have any broad implications for executive authority to restrain constitutionally vested executive discretion.

Professor Michael McConnell suggested that the power followed logically from the executive's power, once a prosecution is initiated, to dismiss a criminal case voluntarily with prejudice. See Michael W. McConnell, Why Have Elections? Using Consent Decrees to Insulate Policies from Political Change, 1987 U. Chi. Legal F. 295, 303, 309. His argument seems to be that, because the executive, through an alternative device, could unilaterally accomplish the same result as a binding nonprosecution agreement entered into without the initiation of any prosecution, the nonprosecution agreement must be valid. If that is so, however, then the President's power to constrain his own discretion is far broader than I had imagined. He could constrain his discretion categorically in any situation in which he could subsequently exercise that discretion on a caseby-case basis to achieve the same result. The President may, for example, veto every environmental bill that Congress passes during his term or pardon every convicted offender of federal law who is a Republican. It follows from Professor McConnell's argument that the President could make a binding promise in advance to veto all environmental bills or pardon all Republican criminals--a position I reject. Assistant Attorney General Cooper suggested, if I understood him correctly, that courts enforce informal nonprosecution agreements to keep their own hands clean. It is not that courts recognize executive authority to confine executive discretion, but rather that courts will not be party to breaches of executive promises regarding the exercise of judicial power. Although Mr. Cooper did not specify the impetus for the judicial stace he asserts, it would not follow logically either as a judicial policy to preserve the integrity of the courts or as a means of enforcing any due process protection owed to defendants. (Professor McConnell's assertion of "due process" and "finality" reasons supporting nonprosecution agreements, id. at 310-11 are inapposite to informal agreements, that is, agreements that ar entered into without the initiation of any prosecution against the protected potential defendant.) First, judicial integrity would not be implicated in entertaining prosecutions initiated in violation of informal executive nonprosecution agreements because courts are not parties to those agreements. It is doubtful, furthermore, that courts possess supervisory power over the executive branch except to control 
judicial procedure and to remedy violations of federal law. See generally Sara Sun Beale, Reconsidering Supervisory Power in Criminal Cases: Constitutional and Statutory Limits on the Authority of the Federal Courts, 84 Colum. L. Rev. 1433 (1984). Second, due process is only weakly implicated in such agreements because they do not involve government representations as to the government's behavior vis-a-vis future private conduct. Finally, courts do permit the executive in some cases to invoke judicial authority in a manner that is inconsistent with executive promises. For example, although some discern a contemporary trend to the contrary, numerous cases hold that administrative agencies are not bound by unauthorized promises by their employees. Thus, the Supreme Court refused to permit as a defense, in a government suit to enjoin the use of public forest land for the construction of an electric power plant, that certain government officers had represented that such a use would be allowed. The Court reasoned that the government could not be estopped by a legally unauthorized promise. Utah Power \& Light Co. v. United States, 243 U.S. 389 (1917). See also Schweiker v. Hansen, 450 U.S. 785 (1981) (Social Security Administration held not liable for insurance benefits for which plaintiff would have applied but for agency official's failure to inform her, as required by agency handbook, of need to apply). Nixon v. Administrator of Government Services, 433 U.S. 425, 443 (1977).

See United States v. Swift \& Co., 286 U.S. 106, 119 (1932).

554 F. Supp. 912 (N.D. Ill. 1983). See note 29 for the entire case history.

See text at notes 29-47.

U.S. Const. art. II, § 3 .

United States v. Board of Educ. of City of Chicago, 567 F. Supp. 272, 286-87 (N.D. Ill. 1983).

United States v. Board of Educ. of City of Chicago, 744 F.2d 1300, 1306 (7th Cir. 1984).

Professor McConnell mischaracterizes this hypothetical in his rebuttal. McConnell, 1987 U. Chi. Legal F. at 311-12, 318-20 (cited in note 74).

This assumption may well be wrong, which would, of course, make my hypothetical wholly unproblematic. Consider, for example, a lawsuit in which, through a consent order or ordinary judgment, the executive is required to pay a certain sum in damages to a particular plaintiff. Presidential sponsorship of legislation forbidding the executive to pay out federal funds in satisfaction of such an obligation would presumably be an unlawful interference with the plaintiff's vested legal rights. This would be true even though a court could not enjoin the President from sponsoring such a bill. See Marbury v. Madison, 5 U.S. 137 (1803) (executive withholding of Justice of the Peace's commission held violative of his vested legal rights although no court possessed jurisdiction to grant a remedy); State of Mississippi v. Johnson, 71 U.S. 475 (1866) (courts may not issue injunctions directing the President in the exercise of discretionary authority). An express presidential promise not to sponsor such legislation would seem permissible because it would amount, in essence, only to a promise to act lawfully.

It is possible to view the President's role vis-a-vis modern administrative lawsuits similarly. Judgments in such lawsuits also create rights in plaintiffs. It is thus arguable that the President would be acting just as unlawfully in seeking legislative sabotage of such a judgment as he would if he sought to impede an ordinary “individual-regarding” judgment in a traditional suit. Consequently, an express promise not to sponsor sabotage legislation would be equally permissible. My chief reservation with this analysis is that the rights guaranteed in "policyregarding" consent decrees are often "rights" that are not possessed in any distinct way by the plaintiffs, but rather executive commitments to perform obligations owed to the public generally. When the executive perceives, subsequent to the entry of a consent decree, that the public interest 
would be better served by a redefinition of its obligations, it is not so obviously irresponsible for the executive to seek to persuade Congress of that view, and it perhaps should not be viewed as contrary to the rule of law. An executive promise never to do so might thus be more problematic than a promise never to seek legislation that would impede an individual-regarding decree. $\underline{42}$ U.S.C. § 2000d (1982).

Peter M. Shane, School Desegregation Remedies and the Fair Governance of Schools, 132 U. Pa. L. Rev. 1041, 1110-11 (1984).

For an argument why courts should lower the standard for granting modifications of consent decrees to protect executive branch discretion, see text at note 105.

See text at note 66.

5 U.S.C. $\S 551$ (1982).

Motor Vehicles Mfrs. Ass'n v. State Farm Mut., 463 U.S. 29, 42 (1983).

United States v. Swift \& Co., 286 U.S. 106, 119 (1932).

See text at notes 12-28.

Heckler v. Chaney, 470 U.S. 821 (1985).

As is well known, Youngstown Co. v. Sawyer, 343 U.S. 579 (1952), invalidated, for lack of statutory or independent presidential authority, the President's order seizing steel mills to insure steel production for the Korean War. Nonetheless, the opinions of six Justices--three dissenters and three in the majority--expressly state that circumstances may exist in which the absence of statutory authority does not preclude presidential initiatives vis-a-vis subject matter that Congress is also empowered to regulate. 343 U.S. at 610-11 (Frankfurter, J., concurring); id. at 637 (Jackson, J., concurring); id. at 662 (Clark, J., concurring); id. at 683 (Vinson, J., dissenting).

In any such case, the President would be acting where his power "is at its lowest ebb, for then he can rely only upon his own constitutional powers minus any constitutional powers of Congress over the matter." Youngstown, 343 U.S. at 637 (Jackson, J., concurring). In the field of domestic economic and social regulation, the President has no apparent constitutional authority that is immune to congressional regulation.

Citizens to Preserve Overton Park v. Volpe, 401 U.S. 402, 415-16 (1971).

In making such a promise, the executive could plausibly assert that it was acting pursuant to an implied authorization by Congress. In this situation, the President's "authority is at its maximum, for it includes all that he possesses in his own right plus all that Congress can delegate.” Youngstown, 343 U.S. at 635 (Jackson, J., concurring). An alternative argument, with identical impact, is that if Congress has neither expressly granted nor denied the President authority to limit his ordinary statutory discretion, then his assertion of authority to do so falls within the "zone of twilight in which he and Congress may have concurrent authority, or in which its distribution is uncertain.” Id. at 637. In particular, the President's power to execute the laws faithfully could colorably be read as embracing a general power to implement the more general purposes that underlie Congress's express statutory commands, and "congressional inertia, indifference or quiescence" invites him to do so. Id.

Vermont Yankee Nuclear Power Corp. v. Natural Resources Defense Council, 435 U.S. 519, 524 (1978) ("Agencies are free to grant additional procedural rights in the exercise of their discretion. ...”).

It is the Attorney General's position that:

(a) In suits actually tried against the United States, courts may not initiate remedial orders that restrict the exercise of ordinarily revisable executive discretion;

(b) “ 
[I]t is

[therefore] constitutionally impermissible for the courts to enter consent decrees containing such provisions. ...” Attorney General's Guidelines at 181 (cited in note 3). This is assertedl so, although “

[t]he Attorney General has plenary authority to settle cases tried under his direction, including authority to enter into settlement agreements that a court could not order if the suit were tried to conclusion.” Id. This position shows the categorical version of the separation of powers in its purest--that is, in its least functionally-oriented--form. Given that settlement agreements are enforceable contracts, the primary practical difference between settlement agreements and consent decrees is that settlement agreements permit the executive to breach and be sued (but not risk contempt as a sanction), while departures from consent decrees risk contempt, among other remedies, unless based on previously granted judicial modifications If this difference is constitutional in magnitude, it is not because of the enforceability of the executive's agreement, but only because of the enforcement procedure involved. However, because courts are reluctant to hold federal agencies or officers in contempt for violating consent decrees (see, for example, In re Attorney General of United States, 596 F.2d 58, 65 (2d Cir. 1979) (holding Attorney General in contempt "should be a last resort, to be undertaken only after all other means to achieve the ends legitimately sought by the court have been exhausted”)), the distinction is of minimal practical significance. Given these practicalities, it is unsurprising that legal support for the Attorney General's argument is weak. 42 U.S.C. $\S 2000$ e-2 (1982).

467 U.S. 561 (1984). That case, however, involved a distinct issue, namely, limitations on a court's power to modify a consent decree in a manner not anticipated in th original decree and over the objections of one of the parties. Id. at 576 n.9.

106 S. Ct. 3063 (1986).

Id. at 3077-78 (citations omitted).

See, for example, Legal Aid Society of Alameda County v. Brennan, 381 F. Supp. 125, 140 (N.D. Cal. 1974), aff'd, 608 F.2d 1319 (9th Cir. 1979).

Indeed, the Justice Department's position that a determination of liability must precede supervisory remedies would seem to apply equally to all remedies. That is, the entry of any consent decree against the government without such a determination would seemingly exceed a court's powers because it would be the imposition of a judicial remedy without a finding of executive branch wrongdoing. By precluding all consent decrees, this insight, of course, would drastically curtail the executive branch's present discretion to conduct litigation in the interest of the United States.

See generally Note, Modification of Consent Decrees in Institutional Reform Litigation, 99 Harv. L. Rev. 1020 (1986). Indeed, a more flexible stance on modification might be more justified in the typical administrative lawsuit than in institutional suits involving constitutional rights. As noted above (see note 4) the governmental discretion limited by constitutional remedies is not so much part of the primary constitutional design as an inevitable artifact of conferring obligations on the government in broad terms. The fact that a constitutional decree interferes with what would otherwise be executive discretion to implement the Constitution does not seem especially troubling so long as the decree represents a good faith agreement by the government and plaintiffs as to how a constitutional mandate should be fulfilled. Administrative law litigation, however, may implicate 
executive discretion that was purposefully left by the Constitution or by Congress to the executive. Courts might legitimately, therefore, be more protective of executive discretion per se in the remedial stage of such lawsuits.

See, for example, Campaign Clean Water, Inc. v. Ruckelshaus, 361 F. Supp 689, 700 (E.D. Va. $\underline{1973)}$.

See, for example, Douglas Laycock, Consent Decrees Without Consent: The Rights of Nonconsenting Third Parties, 1987 U. Chi. Legal F. 103, 128-144.

The most helpful published discussion in terms of data on actual practice is Jeffrey A. Gaba, Informal Rulemaking by Settlement Agreement, 73 Geo. L.J. 1241, 1246-48 (1985), which reports on the role of settlement agreements in EPA rule-making practice.

Id. at 1276.

Fed. Rule Civil Proc. 23(e). See generally Lloyd C. Anderson, The Approval and Interpretation of Consent Decrees in Civil Rights Class Action Litigation, 1983 U. Ill. L. Rev. 579, 589-93.

See 15 U.S.C. $\S 16($ e) (1982) (requiring judicial public interest determination as prerequisite to entry of antitrust consent decrees); 28 C.F.R. § 50.7 (1985) (mandating public notice and comment opportunity before Department of Justice agreement to entry of consent judgments in antipollution cases).

See Gaba, 73 Geo. L.J. at 1267-68 (cited in note 108).

See text at notes 12-59.

Gaba, 73 Geo. L.J. at 1275-76 (cited in note 108).

See Robert L. Rabin, Some Thoughts on the Dynamics of Continuing Relations in the Administrative Process, 1985 Wis. L. Rev. 741, 746.

Indeed, there is no certainty, even in cases pressed to judgment, that the relief imposed on an agency is unwelcome. An agency may contest a complaint only nominally to secure a "friendly" judgment against itself without the appearance of collusion.

5 U.S.C. $\S 553$ (1982).

See Rabin, 1985 Wis. L. Rev. at 746 (cited in note 115); Richard B. Stewart, The Discontents of Legalism: Interest Group Relations in Administrative Regulation, 1985 Wis. L. Rev. 655, 660-66 (1985).

See Stephen G. Breyer and Richard B. Stewart, Administrative Law and Regulatory Policy 168172 (2d ed. 1985).

See Lewis L. Jaffe, The Illusion of the Ideal Administration, 86 Harv. L. Rev. 1183, 1188-91 (1973). Even so, the debate whether agency capture always disserves the public interest is not wholly one-sided. See Stewart, 1985 Wis. L. Rev. at 665-66 (cited in note 118).

Rabin, 1985 Wis. L. Rev. at 747 (cited in note 115).

See, for example, Joel F. Handler, Continuing Relationships and the Administrative Process: Social Welfare, 1985 Wis. L. Rev. 687, 691-99 (arguing for cooperative decisionmaking in the administration of special education); Philip J. Harter, Negotiating Regulations: A Cure for Malaise, 71 Geo. L.J. 1 (1982) (offering negotiated rule making as a solution to problems characteristic of regulation under an adversary model).

Melvin A. Eisenberg, Private Ordering through Negotiation: Dispute-Settlement and Rulemaking, 89 Harv. L. Rev. 637, 638 (1976).

Id.

Id. at 638-65.

Id.

Id. at 665-72. 
Commenting on an earlier draft, Professor Peter Strauss remarked that he is wary of assessments such as these concerning the government's litigating resources. Perhaps most tellingly, he emphasizes that the demands on government litigating agencies are uniquely great, so that the "opportunity cost" to the government of matching private resources devoted to any particular suit may be prohibitive. Nonetheless, based on my own more limited experience as a government lawyer, I find it difficult to believe that the federal government is regularly giving up more than it should in settlements because of an imbalance in resources.

Eisenberg, 89 Harv. L. Rev. at 638 (cited in note 123).

Owen F. Fiss, Against Settlement, 93 Yale L.J. 1073, 1085 (1984).

Id.

Id.

Id. at 1082-85.

This paragraph apparently aligns me with Judge Easterbrook in entertaining at least a rebuttable preference for dispute settlement by agreement. See Frank H. Easterbrook, Justice and Contract in Consent Judgments, 1987 U. Chi. Legal F. 19. I differ, however, in one major respect from Judge Easterbrook's adherence to the contract model in divining the scope of appropriate settlement authority for government agencies. See also McConnell, 1987 U. Chi. Legal F. at 300-04 (cited in note 74) (executive power to constrain discretion not expanded when negotiating consent decrees). The executive's contracting power emanates from Congress, not from the common law, and Congress may well have reasons to confer more or less contracting authority in the litigation settlement context than in other areas. It is thus not possible to adopt any easy assumption that the scope of government contracting power in settlement and in, say, ordinary procurement, is identical, while analogous assumptions about the authority of private individuals might be sensible.

INS v. Chadha, 462 U.S. 919 (1983) (invalidating so-called "legislative vetoes” as violative of the bicameralism requirement and Presentment Clauses of Article I); Bowsher v. Synar, 106 S. Ct. 3181 (1986) (invalidating, because of the Comptroller General's removability by Congress, his mandatory authority over the executive under the Balanced Budget and Emergency Deficit Control Act of 1985, 2 U.S.C.A. § 901 (West Supp. 1986)). Although commentators have used Chadha and Bowsher in defense of the "categorical model" of the separation of powers, these cases actually dealt with discrete procedural questions that the Constitution addresses with unusual explicitness, and may have little impact on the adjudication of broader separation of powers concerns.

For recent examples of functional analysis applied to separation of powers issues, see Commodity Future Trading Commission v. Schor, 106 S. Ct. 3245 (1986) (upholding quasi-judicial agency authority to resolve state common law counterclaims in an administrative proceeding); Thomas v. Union Carbide Agricultural Prod. Co., 473 U.S. 568 (1985) (upholding quasi-judicial agency authority to resolve state common law counterclaims in an administrative proceeding); Thomas v. Union Carbide Agricultural Prod. Co., 473 U.S. 568 (1985) (upholding quasi-judicial agency power to adjudicate compensation owed to pesticide manufacturer for a second manufacturer's use of the first's research data in connection with the second's application for pesticide registration); Harlow v. Fitzgerald, 457 U.S. 800 (1982) (holding presidential advisers entitled to only qualified immunity in suits for damages based on alleged unconstitutional conduct in office); Nixon v. Administrator of General Services, 433 U.S. 425 (1977) (upholding congressional regulation of control over and access to President Nixon's confidential records). 
The "categorical model" is the most formalistic response to a persistent malaise in administrative law--a disquiet concerning just how we are to picture or "model" federal administrative process in view of the ubiquitous presence of administrative discretion. For a general discussion of this theme, see Robert L. Rabin, Administrative Law in Transition: A Discipline in Search of an Organizing Principle, 72 Nw. U.L. Rev. 120 (1977). Courts and commentators early recognized the threat to the "categorical model" that is posed by the so-called "independent” administrative agencies, which promulgate, enforce, and interpret their own rules. Humphrey's Executor v. U.S., 295 U.S. 602, 628 (1935); James M. Landis, The Administrative Process 115 (1938). Yet, even for administrators squarely within the executive branch, the model does not hold. Simple awareness of these officials' discretion over policy formulation, execution, and review renders problematic any attempted constitutional compartmentalization of their tasks. Excluding the President, the Supreme Court's one-time reference to "purely executive officers," Humphrey's Executor, 295 U.S. at 632, seems to describe an empty set. (Even the Vice-President, who presides over the Senate, U.S. Const. art. I, § 3, par. 4, exercises some legislative power.) Notwithstanding the theoretical problems that attend the "categorical model," the Reagan Administration has staunchly adhered to it. Examples include the search for judges who avow a philosophy of self-restraint in their review of decisions by elected officials, see, for example, President's White House Briefing, 21 Weekly Comp. Pres. Doc. 1276, 1278 (Oct. 21, 1985), and the Administration's attempted broad-gauged assertions of executive privilege against Congress. Peter M. Shane, Legal Disagreement and Negotiation in a Government of Laws: The Case of Executive Privilege Claims Against Congress, 71 Minn L. Rev. 461, 501-14 (1987) (discussing Reagan Administration executive privilege disputes concerning former Secretary of the Interior James Watt and former Environmental Protection Agency Administrator Anne Gorsuch Burford). Other examples include opposition to the legislative veto--a long-standing executive cause, see, for example, INS v. Chadha, 462 U.S. 919, 928 (1983) (detailing Justice Department opposition to one-House veto of deportation stay); challenges to the authority of the Comptroller General, an official not subject to presidential removal, to issue orders that bind the executive in any aspect of government administration, http://www.westlaw.com/Find/Default.wl?rs=dfa1.0\&vr=2.0\&DB=708\&FindType=Y\&SerialNu $\mathrm{m}=1986134545$ (invalidating, with executive concurrence, Comptroller General's role in implementing the Balanced Budget and Emergency Deficit Control Act of 1985); Ameron, Inc. v. U.S. Army Corps of Engineers, 787 F.2d 875 (3d Cir. 1986) (upholding, over executive objections, Comptroller General's role in implementing the Competition in Contracting Act of 1984); McDonnell Douglas Corp. v. United States, 754 F.2d 365 (Fed. Cir. 1985) (upholding, over executive objections, Comptroller General's subpoena powers under General Accounting Office Act of 1980); United States v. McDonnell Douglas Corp., 751 F.2d 220 (8th Cir. 1984) (same); and efforts to narrow the use of special masters in government litigation, Memorandum from Attorney General Edwin Meese III to All Assistant Attorneys General and All United States Attorneys Re: Department Policy Regarding Special Masters (March 13, 1986). In each of these efforts, the Department of Justice has argued the constitutional invalidity of institutional practices that the Administration disapproves. The Attorney General's latest initiative on behalf of this "pure" version of the separation of powers is a speech insisting that Supreme Court decisions do not create "a supreme law of the land that is binding on all .. . parts ofgovernment, henceforth and forevermore.” Stuart Taylor, Jr., Meese Says Rulings By US High Court Don't Establish Law, N.Y. Times, Oct. 23, 1986, p. 1, col. 6. Attorney General's Guidelines (cited in note 3). 
U.S. Department of Justice, Office of Legal Counsel, Press Release 1 (March 21, 1986) (copy on file with the University of Chicago Legal Forum).

Id.

This significance is signaled not only by the covering memorandum, but also by the high level of attention the Guidelines received in the Department and by the press conference that accompanied their issuance. The Guidelines originated with an interdivisional Department of Justice working group that based its recommendations chiefly on the professional experiences and perceptions of the working group's members, and not on a body reported decisions, or a written report analyzing the problems of discretion-limiting decrees. Telephone Interview with Charles J. Cooper, Assistant Attorney General, U.S. Department of Justice, Office of Legal Counsel (July 3, 1986). To be fair, the absence of a large base of reported judicial decisions substantiating the existence of problems worth remedying does not belie the Justice Department's perceptions in this respect because the settlements are often not reflected in reported decisions.

Attorney General's Guidelines at 180 (cited in note 3).

Id. at 181.

Gerald R. Williams, Legal Negotiation and Settlement 95-102 (1983). The distinction is yet more puzzling because courts may enforce breached settlement agreements summarily under their equity powers, further blurring the distinction between settlement agreements and consent decrees. Timothy S. Jost, Commentary: The Attorney General's Policy on Consent Decrees and Settlement Agreements, 39 Admin. L. Rev. 101, 102 and n.2 (1987).

Attorney General's Guidelines at 182 (cited in note 3) (emphasis added).

Id. (emphasis added).

Id. (emphasis added).

Id. at 182-83.

Id. at 182.

Id. at 183 (emphasis added).

U.S. Const. art. II, $\S 1$, par. 1. The Constitution speaks of subordinate administrative officers only in reference to their manner of appointment, U.S. Const. art. II, $\S 2$, par. 2, their liability for impeachment, U.S. Const. art II, § 4, and the President's authority to request written opinions from the heads of departments. U.S. Const. art. II, § 2, par. 1.

Indeed, I think it a fair guess that the Attorney General's Guidelines were substantially motivated not by concerns about discretion-limiting consent decrees per se, but by an aversion to the recognition of any statutory cause of action permitting judicial supervision of administrative policy.

Alternatively, it may be that the Attorney General actually prefers to litigate suits of the kind described above in Part I of this article because, if the executive finds a judge who shares the Attorney General's sentiments, the executive branch may avoid any liability for, say, the systematic nonenforcement of a statute. A sympathetic judge may read the underlying statutory duty narrowly or avoid the claim for coercive relief on procedural grounds. Fueling that hope, however, would be about as far as the Guidelines could go in avoiding discretion-limiting remedies. The reason is that the causes of action that lead to such remedies are rooted in many regulatory statutes. The Supreme Court may facilitate more or less stringent judicial supervision of administration under these laws through its own approaches to statutory interpretation. Only Congress, however, can systematically uproot the vision of public law against which the Attorney General rebels, and it 
does not yet appear much interested in doing so. Richard B. Stewart, The Reformation of American Administrative Law, 88 Harv. L. Rev. 1667 (1975).

Richard B. Stewart and Cass R. Sunstein, Public Programs and Private Rights, 95 Harv. L. Rev. 1195 (1982).

Stewart, 88 Harv. L. Rev. at 1669-70 (cited in note 152).

Id. at 1756 .

Id. at 1760 .

Stewart and Sunstein, 95 Harv. L. Rev. at 1205-06 (cited in note 153).

See, for example, Dunlop v. Bachowski, 421 U.S. 560 (1975) (upholding reviewability of agency failure to challenge union election allegedly in violation of the Labor Management and Reporting Act of 1959, 29 U.S.C. § 400-531). As Dunlop illustrates, the distinction between agency inaction and inadequate agency action cannot be pressed very far. A non-prosecution decision, after all, is not only a failure to prosecute, it is the affirmative adoption of a policy that other possible agency functions take priority.

See, for example, Sierra Club v. Costle, 657 F.2d 298 (D.C. Cir. 1981).

Stewart and Sunstein, 95 Harv. L. Rev. at 1205 (cited in note 153).

See, for example, D.C. Federation of Civic Associations v. Volpe, 459 F.2d 1231, 1249 (D.C. Cir. 1971).

See, for example, Public Citizen Health Research Group v. Auchter, 702 F.2d 1150, 1157-58 (D.C. Cir. 1983).

See generally Abram Chayes, The Role of the Judge in Public Law Litigation, 89 Harv. L. Rev. 1281 (1976).

See note 136.

See Peter L. Strauss, The Place of Agencies in Government: Separation of Powers and the Fourth Branch, 84 Colum. L. Rev. 573, 578 (1984).

Congress's executive-type powers include the power of impeachment, U.S. Const. art. I, § 2, par. 5, and the Senate's authority to advise and consent on treaties and administrative appointments, art. II, § 2, par. 2. The Senate conducts trials following impeachment, art. I, § 3, par. 6, seemingly exercising a judicial power. The President's most obvious legislative-type power is his power to veto legislation he disapproves, art. I, § 7, pars. 2 and 3. He also possesses the judicial-type pardon power, art. II, $\S 2$, par. 1 . The Constitution does not specify the powers of the judiciary, except for the decision of cases. Yet, it is commonly perceived that the "judicial power" vested by article III encompasses some power to make common law, a legislative-type power, and the executive-type power to charge with contempt.

Merrick B. Garland, Deregulation and Judicial Review, 98 Harv. L. Rev. 505, 586 (1985).

Cass R. Sunstein, Factions, Self-Interest and the APA: Four Lessons Since 1946, 72 Va. L. Rev. 271, 278 (1986).

Judgments that constrain the executive to follow Congressional enactments perfect rather than impede our democratic system. Such decrees should be added to Professor McConnell's catalogue of traditional means for giving "governmental policy ... the force and effect of law." McConnell, 1987 U. Chi. Legal F. at 296 (cited in note 74).

Garland, 98 Harv. L. Rev. at 586-90 (cited in note 167).

See generally Theodore Eisenberg and Stephan C. Yeazell, The Ordinary and the Extraordinary in Institutional Litigation, 93 Harv. L. Rev. 465 (1980).

Id. at 488-91.

Id. at 516. 
This is not to say, of course, that the courts--most notably, the Supreme Court--do not have a major role to play. Because, for example, the Administrative Procedure Act provides so little guidance on informal administrative procedure, it is arguable that the courts and not Congress have gone farthest in establishing the law of informal rule making and adjudication. See, for example, Citizens for Overton Park v. Volpe, 401 U.S. 402, 420 (1971) (creating judicial review on an "administrative record" of wholly informal decisions). It will be interesting in this regard to view the performance of the Supreme Court's newest Justice, Antonin Scalia, who is an eminent administrative law scholar. Nonetheless, it remains true that any wholesale effort to redirect the system of American regulatory law will have to emanate from the legislature empowered to provide for our system of public regulation.

The President has recently reactivated his Task Force on Regulatory Relief to pursue this possibility.

See generally Stewart, 1985 Wis. L. Rev. 655 (cited in note 118); Richard B. Stewart, Beyond Delegation Doctrine, 36 Am. U.L. Rev. 323 (1987).

See Stewart and Sunstein, 95 Harv. L. Rev. at 1199 (cited in note 153).

Congress's institutional interests do not necessarily militate in favor of any such proposal, however; nor do the political interests of conservative Republicans. Unreviewable discretion in James Watt's hands one day will become unreviewable discretion in Cecil Andrus's another. The fantasy that the people's choice of an ideologically committed President repudiates all the policies of his predecessor that are contrary to that ideology is one that no Reaganite would utter should Democrats recapture the White House in 1988. It is not a sound model on which to build administrative law.

It is worth underscoring that the Administration's policy is to maximize presidential, not subordinate agency, discretion. This is evident from its innovations in the centralization of executive regulatory oversight in the Office of Management and Budget, see Shane, Presidential Regulatory Oversight and the Separation of Powers: The Constitutionality of Executive Order No. 12,191, 23 Ariz. L. Rev. 1235, 1245 (1981); Note, Presidential Policy Management of Agency Rules Under Reagan Order 12,498, 38 Admin. L. Rev. 63 (1986); and from the Administration's expressed doubts as to the constitutionality of independent regulatory agencies. See Stuart Taylor, Jr., A Question of Power, A Powerful Questioner, N.Y. Times, Nov. 6, 1986 p. B8, col. 3 (commenting on Sept. 13, 1985 address of Attorney General Meese to Federal Bar Association). McConnell, 1987 U. Chi. Legal F. at 305-08 (cited in note 74). As Professor Jost observes, however, the Guidelines do not absolutely preclude decrees that bind later administrations because the Attorney General retains plenary authority to approve any decree. Jost, 39 Admin. L. Rev. at 104-05 (cited in note 143).

McConnell, 1987 U. Chi. Legal F. at 300-01, 318-21. With respect, I dissent strongly from Professor McConnell's view of the presidency, which lies at the core of our disagreement generally. Contrary to his assertions, it says little about the issues at hand that presidents are limited to four-year terms. Presidents do, notwithstanding their limited terms, exert some effective control over the discretion of their successors. (Most obviously, a president binds his successors to treat as law any Congressional enactments that the President signs into law, and disables his successors from treating as law any bills he vetoes that Congress does not enact by two-thirds vote.) The question is not whether presidents may ever limit their successors' discretion, but the extent to which they may do so. 
Nor does it prove anything that Congress could not, as Professor McConnell argues (and I agree), permit one president to constrain his successors' constitutionally based discretion beyond the degree to which the Constitution gives a president such authority. The issue Professor McConnell short changes is whether Congress may permit presidents to constrain future administrators in the exercise of their statutorily based discretion. It is not a persuasive answer to argue that Congress, in so doing, would be authorizing intrusions into later presidents' power "to take Care that the Laws be faithfully executed." If the laws Congress passes enable one president to curtail the enforcement discretion of later administrations, and a president invokes such authority, then later administrations, implementing their curtailed discretion, are faithfully executing the laws, as Congress has enacted them; no constitutional power has been lost. $1987 \mathrm{U}$. Chi. Legal F. 241 